\title{
ULAGANJE U ISTRAŽIVANJE I RAZVOJ - ČIMBENIK GOSPODARSKOG RASTA REPUBLIKE HRVATSKE
}

\author{
INVESTMENT IN RESEARCH AND DEVELOPMENT \\ - THE FACTOR OF ECONOMIC GROWTH \\ OF THE REPUBLIC OF CROATIA
}

SAŽETAK: Republika Hrvatska je 2013. godine postala članica Europske unije, čime je ostvarila svoj najvažniji gospodarski i politički cilj. Međutim, nespremnost i nedovoljna prilagođenost novim gospodarskim uvjetima rezultirala je zaostajanjem za ostalima, a posebno novim zemljama članicama. Kao ključni element prilagodbe gospodarstvu EU te ostvarenja gospodarskoga rasta određena su ulaganja u istraživanje i razvoj. Provedenom analizom je utvrđeno zaostajanje Republike Hrvatske u svim gospodarskim aspektima te aspektima ulaganja u istraživanje i razvoj. Kako bi prevladala postojeće gospodarske i socijalne razlike, Republika Hrvatska mora težiti ostvarenju ciljeva propisanih strategijom EUROPA 2020 te nacionalnim razvojnim i istraživačkim strategijama te stvoriti temelje za provođenje efikasnih strukturnih reformi. Projekcije ulaganja u istraživanje i razvoj ukazuju na njihov kontinuirani rast do 2020. godine, a što će imati značajnu ulogu u smanjenju razvojnih razlika i tranziciji Republike Hrvatske u europsko društvo znanja.

KLJUČNE RIJEČI: EU, gospodarski rast, Republika Hrvatska, ulaganje u istraživanje i razvoj.

ABSTRACT: In 2013 the Republic of Croatia achieved its most important economic and political goal and became a full member of the EU. However, unpreparedness and lack of adaptation to new economic conditions resulted in lagging behind other EU member states, particularly new member states. In this situation, investments in research and development are determined as a key factor of Croatian adjustment to the EU economy and the achievement of economic growth. Carried out analysis shows Croatia's lagging behind in all economic aspects and aspects of investment in research and development. In order to overcome the current economic and social disparities, Croatia should aspire towards realization of the EUROPE 2020 objectives and other national develop-

Dr. sc. Marko Tomljanović, asistent, Sveučilište u Rijeci, Ekonomski fakultet Rijeka, Ivana Filipovića 4, 51000 Rijeka, E-mail: marko.tomljanovic@efri.hr, mtomljanovic98@gmail.com, Tel. 051355 130/098 1729779 
ment and research strategies and create the foundation for effective implementation of structural reforms.

Projections of investment in research and development indicate their continued growth by 2020, which will have a significant role in reducing development disparities and transition of Republic of Croatia to the „European knowledge society“.

KEY WORDS: economic growth, EU, investment in research and development, Republic of Croatia.

\section{UVOD}

Republika Hrvatska je 2013. godine ostvarila svoj dugogodišnji gospodarski i strateški cilj te postala punopravna članica Europske unije. Očekivanja od prvih godina članstva bila su velika i optimistična, a posebno sa stajališta ostvarivanja koristi od poslovanja na unutarnjem tržištu EU te općenito sudjelovanja u cjelokupnom gospodarskom i političkom sustavu Unije. Ipak, značajnije i vidljivije koristi su zasada izostale, a što je prije svega posljedica dugotrajne globalne gospodarske krize, kojom su Republika Hrvatska i ostale zemlje članice EU bile uvelike pogođene.

Problem provedenoga istraživanja proizlazi iz nepovoljnoga gospodarskog i socijalnog stanja u Republici Hrvatskoj, obilježenoga niskim razinama BDP-a per capita, visokim stopama nezaposlenosti te nepovoljnom gospodarskom strukturom i strukturom zaposlenosti. Nadalje, Republika Hrvatska, premda je kao ključni cilj proklamirala ostvarenje ekonomije znanja, još uvijek ima vrlo niske razine ulaganja u istraživanje i razvoj, nepovoljnu obrazovnu strukturu te nedovoljnu komercijalizaciju produkata ulaganja u istraživanje i razvoj. Također, produkti obrazovanja nisu potpuno stavljeni u funkciju postizanja gospodarskog boljitka. Navedena situacija usporava ostvarivanje daljnjega rasta hrvatskoga gospodarstva te smanjenje zaostajanja u odnosu na razvijene zemlje članice EU. Republika Hrvatska se stoga mora okrenuti provedbi efikasnih strukturnih reformi te ostvarenju gospodarskoga rasta i konvergencije.

Kandžija i Cvečić (2010.) definiraju konvergenciju kao proces sustavnoga smanjenja razvojnih razlika između zemalja i regija. Također, autori ističu kako konvergencija podrazumijeva vremensku dimenziju i uvjete koji određuju brzinu i smjer njezina djelovanja. U razmatranju konvergencije je također važno istaknuti i Sala i Martina (1996.), koji uvode pojmove sigme i beta konvergencije. Pritom, sigma konvergencija, podrazumijeva smanjivanje razlika u realnim dohocima per capita u određenome razdoblju, dok beta konvergencija, u načelu pretpostavlja brži rast siromašnijih regija u odnosu na bogate. Također, beta konvergencija podrazumijeva negativnu vezu razina realnoga dohotka per capita na kraju i na početku promatranoga razdoblja. Naime, ako je $\beta<0$, tada sve zemlje konvergiraju prema zajedničkom stabilnom stanju. Ipak, u teoriji ne postoje dokazi apsolutne beta konvergencije, već je dokazana uvjetovana beta konvergencija, koja nalaže kako skupine zemalja (regija) konvergiraju specifičnoj razvojnoj razini, a koja je uvjetovana različitim strukturnim obilježjima (npr. razine tehnologije, stope štednje, stope rasta stanovništva itd.). Općenito, uvjetovana beta konvergencija ističe kako, iako neka zemlja raste brže, ona ne sustiže nužno razinu dohotka per capita u nekoj bogatoj zemlji, tj. razlike u dohocima per capita se ne moraju nužno smanjivati s beta konvergencijom. Suvremeni uvjeti poslova- 
nja te globalizacijska kretanja, preusmjerila su pozornost na nove čimbenike konvergencije, pri čemu se velika važnost pridaje ljudskome kapitalu, tj. njegovome napretku kroz obrazovanje i usavršavanje (Bjorksten, 2000.) te ulaganjima u istraživanje i razvoj i njihovim produktima (Fagerberg et al., 1997. i Armstrong i Taylor, 2000.), a što predstavlja polazište za istraživanje provedeno u ovome radu.

Temeljem svega navedenoga, cilj istraživanja je prezentirati ključne teorijske čimbenike koji ukazuju na važnost ulaganja u istraživanje i razvoj u procesu ostvarenja gospodarskoga rasta, analizirati gospodarsko stanje Republike Hrvatske te predložiti smjernice za budući razvoj. Nadalje, svrha provedenoga istraživanja je analizom ulaganja u istraživanje i razvoj, a koja predstavljaju temeljni suvremeni ekonomski resurs, ukazati na njihovu važnost u procesu ostvarenja gospodarskoga oporavka hrvatskoga gospodarstva.

Rad se sastoji od 7 međusobno povezanih dijelova. Istraživanje počinje uvodnim razmatranjima u kojima su definirani problem, predmet te svrha i cilj istraživanja. Na uvodni dio se nastavlja objašnjenje metodologije te prikaz prethodnih istraživanja koja identificiraju ulaganja u istraživanje i razvoj kao čimbenik ostvarenja gospodarskoga rasta. Središnji dio rada čini analiza gospodarskoga stanja u Republici Hrvatskoj, koja ukazuje na zaostajanje i potrebu orijentacije na suvremene „,motore“ rasta, tj. ulaganja u istraživanje i razvoj. Analiza ulaganja u istraživanje i razvoj je provedena u 5. dijelu. Sedmi dio rada je usmjeren analizi relevantnih europskih i hrvatskih razvojnih i znanstveno-istraživačkih strategija. Također, temeljem analize strategija, predložen je i autorski koncept budućega razvoja hrvatskoga gospodarstva te primjenom metode eksponencijalnoga izglađivanja provedena projekcija kretanja ulaganja u istraživanje i razvoj do 2020. godine. Rad završava zaključkom, koji predstavlja sintezu ključnih rezultata provedenoga istraživanja.

\section{METODOLOGIJA ISTRAŽIVANJA}

U radu je provedena analiza gospodarskoga stanja te analiza ulaganja u istraživanje i razvoj u Republici Hrvatskoj i EU.

Pritom, kao ključni pokazatelji gospodarskoga stanja su analizirani: 1) BDP per capita (u eurima), 2) stopa rasta BDP-a (\%), 3) dodana vrijednost primarnoga, sekundarnoga i tercijarnoga sektora BDP-u (\% BDP-a), 4) zaposlenost u primarnome, sekundarnome i tercijarnome sektoru (\% ukupne zaposlenosti), 5) stopa nezaposlenosti (\% aktivnoga stanovništva), 6) stopa zaposlenosti (\% aktivnoga stanovništva 15-64 godine).

Nadalje, stanje ulaganja u istraživanje i razvoj je analizirano kroz: 1) ulaganja u istraživanje i razvoj (\% BDP-a), 2) ulaganja u istraživanje i razvoj per capita (u eurima), 3) struktura ulaganja u istraživanje i razvoj, tj. ulaganja poslovnoga, javnoga i sektora visokoga obrazovanja (\% BDP-a), 4) obrazovna struktura aktivnoga stanovništva (udio (\%) stanovništva sa završenim sekundarnim i tercijarnim obrazovanjem 25-64 godine, 5) udio proizvoda visoke tehnologije u ukupnome izvozu prerađivačke industrije (\%) te 6) udio stanovnika koji sudjeluju u programima cjeloživotnoga obrazovanja (\% stanovništva 25-64 godine). Također, u obzir je uzet pokazatelj novih doktora znanosti na 1.000 stanovnika te broj istraživača na milijun stanovnika. Istraživanje je temeljeno na podacima prikupljenim iz sekundarnih međunarodnih statističkih baza (Eurostat, Svjetska banka). Istraživanjem je, ovisno o dostupnosti podataka, obuhvaćeno razdoblje od 2003. (2004.) do 2015. (2016.) godine. 
U radu je provedena projekcija kretanja razina ulaganja u istraživanje i razvoj (\% BDP-a) primjenom metode eksponencijalnoga izglađivanja, koja se uobičajeno koristi kod vremenskih serija. Korištenjem ove metode prognoza za razdoblje se dobiva kao ponderirani prosjek stvarne i prognozirane vrijednosti vremenske serije u razdoblju t. Stvarnoj vrijednosti vremenske serije u razdoblju pridružuje se ponder w (konstanta izglađivanja), koji poprima vrijednost između 0 i 1, dok se prognozi t pridodaje ponder. Što je veća vrijednost parametra, veći je i ponder koji se pridodaje prethodnome razdoblju (Winters, 1960.).

Metoda Holt-Winters koristi trostruko zaglađivanje i ima tri konstante izglađivanja:

1) konstanta koja se koristi kod svakog eksponencijalnog izglađivanja (overall smoothing)

2) konstanta koja se koristi kod određivanja trenda kretanja vrijednosti (trend smoothing)

3) konstanta koja se koristi kod određivanja periodičnosti vrijednosti (seasonal smoothing).

Predviđanje se izračunava temeljem sljedećih formula:

$$
\begin{gathered}
\mathrm{S}_{\mathrm{t}}=\alpha \mathrm{y}_{\mathrm{t} / \mathrm{t}-\mathrm{L}}+(1-\alpha)\left(\mathrm{S}_{\mathrm{t}-1}+\mathrm{b}_{\mathrm{t}-\mathrm{L}}\right) \\
\mathrm{b}_{\mathrm{t}}=\mathrm{y}\left(\mathrm{S}_{\mathrm{t}}-\mathrm{S}_{\mathrm{t}-1}\right)+(1-\mathrm{y}) \mathrm{b}_{\mathrm{t}-1} \\
\mathrm{I}_{\mathrm{t}}=\beta \mathrm{y}_{\mathrm{t}} / \mathrm{S}_{\mathrm{t}}+(1-\beta) \mathrm{I}_{\mathrm{t}-\mathrm{L}} \\
\mathrm{F}_{\mathrm{t}+\mathrm{m}}=\left(\mathrm{S}_{\mathrm{t}}+m b_{\mathrm{t}}\right) \mathrm{I}_{\mathrm{t}-\mathrm{L}+\mathrm{m}}
\end{gathered}
$$

gdje su

$\mathrm{y}=$ promatrane vrijednosti

$\mathrm{S}=$ izglađene vrijednosti

$\mathrm{b}=$ faktor trenda vrijednosti

$\mathrm{I}=$ indeks periodičnosti vrijednosti

$\mathrm{f}=$ predviđanje za $\mathrm{m}$ perioda unaprijed

$\mathrm{t}=$ indeks koji označava vremenski period.

\section{PRETHODNA ISTRAŽIVANJA}

Razmatranje važnosti ulaganja u istraživanje i razvoj kao čimbenika ostvarenja gospodarskog rasta aktualizirano je u 50-im i 60-im godinama 20. stoljeća u okviru neoklasične teorije gospodarskoga rasta. Navedena se teorija temelji na postavkama Solow-Swanovoga modela, u kojemu je, uz tradicionalne faktore proizvodnje (rad i kapital), tehnologija određena kao ključni čimbenik ostvarenja gospodarskoga rasta u dugom roku (Solow, 1956.). Pritom, tehnološki napredak je određen kao nusprodukt ulaganja u fizički kapital u poduzećima. Solow (1957.) razmatra situacije kada nema tehnološkoga napretka, tj. razina tehnologije je konstantna te situacija u kojoj postoji tehnološki napredak, tj. razina tehnologije je promjenljiva.

Daljnja razmatranja ulaganja u istraživanje i razvoj kao čimbenika ostvarenja gospodarskoga rasta su nastavljena u 80-im i 90-im godinama 20. stoljeća u okviru endogenog modela gospodarskoga rasta. Za razliku od neoklasičnih ekonomista, endogeni teoretiča- 
ri odbacuju pretpostavku o znanju kao javnome dobru te mu dodjeljuju tržišnu osobinu, s ključnim obilježjima suparništva i isključivosti. Endogeni ekonomisti nadograđuju dosadašnje neoklasične pretpostavke te određuju akumulaciju znanja kao ključni čimbenik ostvarenja gospodarskoga rasta. Nadalje, Romer (1986.) ističe kako prelijevanje znanja rezultira pozitivnim učincima u vidu tehnoloških inovacija te naglašava kako povećanje proizvodnje izravno ovisi o količini radne snage uključene u procese istraživanja i razvoja (Romer, 1990.).

Uz Romera, kao najznačajnije endogene teoretičare potrebno je istaknuti i Lucasa (1988.), Grossmana i Helpmana (1990.) te Aghiona i Howitta (1992.), koji ističu kako poduzeća svjesno ulažu u istraživanje i razvoj, kako bi stvorila nove proizvode, a što predstavlja temelj razvoja suvremene znanstvene misli u ovome području. Također, prema Grossmanu i Helpmanu (1990.), tehnološki razvoj je objašnjen rastom broja proizvoda, a koje se pojednostavljeno izjednačava s procesom razvoja inovacija.

Pri razmatranju ulaganja u istraživanje i razvoj u kontekstu ostvarenja gospodarskoga rasta, potrebno je značajnu pozornost obratiti i na važnost obrazovanja. Povezanost obrazovanja i ostvarenja rasta BDP-a je razmatrana u radovima Mincera (1974.), Easterlina (1981.) te Stevensa i Wealea (2003.). Pereira i Aubyn (2009.) te Solaki (2013.), analizom Portugala i Grčke, promatraju obrazovanje s makroekonomskoga stajališta, dok Bouaissa (2009.) i Ahmed (2009.) to čine s mikroekonomskoga stajališta. Puljiz (2009.), istraživanjem provedenim na razini Republike Hrvatske, naglašava važnost stanovništva sa završenim srednjoškolskim obrazovanjem u procesu ostvarivanja gospodarskoga rasta, a što proizlazi iz veće zastupljenosti visokoobrazovane radne snage u sektorima niske produktivnosti.

Suvremeni koncepti razvijeni u 2000-tim godinama, uvode nove pojmove kao npr. «novi industrijski prostor», «industrijski klasteri», «inovativni milje», «samoučeća regija» ili «regionalni inovativni sustav» (Lawson, 1997.). Audretsch i Feldman (1997.) analiziraju važnost geografskog prostora u procesu prenošenja znanja i informacija. Prema ovim autorima, cijena prenošenja znanja raste kako se povećava geografska udaljenost te kao najefikasniji instrument njegova prijenosa identificiraju učestalu komunikaciju, tj. sustav licem u lice. Grilliches (1998.) i Barro (1998.) objašnjavaju utjecaj povećanja razine ulaganja u istraživanje i razvoj na ukupnu produktivnost na razini poduzeća, industrije i cjelokupnoga gospodarstva.

Chesire i Malecki (2005.), uvođenjem pojma prostornih inovacijskih sustava ističu važnost koncentracije visokoinovativnih poduzeća koja konstantno i planski ulažu u nove tehnologije, uz održavanje bliskih međusobnih veza s ostalim važnim akterima u regiji, a posebno obrazovnim institucijama, lokalnim i regionalnim vlastima itd. Nadalje, Aghion et al. (2005.) naglašavaju važnost ulaganja u istraživanje i razvoj kao ključnoga pokretača socio-ekonomskih promjena. Naime, autori ističu kako najrazvijenije zemlje reagiraju na ekonomsku globalizaciju kroz promicanje znanstvene i tehnološke politike, u svrhu osiguranja konkurentskih prednosti i stvaranja novih radnih mjesta te predstavljaju instrument rješavanja rastućih globalnih problema. Šimurina (2004.) analizira tehnološke performanse zemalja središnje i istočne Europe. Autor zaključuje kako se izvori rasta razlikuju među promatranim zemljama, ističući pritom dominaciju Mađarske i Češke u izvozu proizvoda visoke tehnologije, dok s druge strane, Slovenija zauzima vodeće pozicije u broju patentnih prijava, angažiranosti istraživača te ukupnim ulaganjima u istraživanje i razvoj. Također, autor ističe kako je pri planiranju budućih razvojnih strategija potrebno uvelike uzeti u 
obzir i povijesna nasljeđa. Nadalje, sagledavanjem iste skupine zemalja Šimurina (2006.) zaključuje kako tehnologija ima određeni utjecaj na razvoj ove skupine zemalja. Međutim, transferi tehnologije se u ovome slučaju nisu pokazali značajno učinkovitima u poticanju gospodarskoga napretka. Audretsch et al. (2006.) ističu važnost sveučilišta kao nositelja gospodarskoga rasta, stvaranja radnih mjesta te ostvarivanja međunarodne konkurentnosti. Rezultati njihova istraživanja ukazuju na sklonost znanstvenika pokretanju poduzetničkih aktivnosti te, kroz nju, komercijalizaciju vlastitih inovacija.

U razmatranju ulaganja u istraživanje i razvoj kao čimbenika ostvarenja gospodarskoga rasta i konvergencije Fagerberg et al. (1997.) i Mankiew et al. (1992.), prihvaćaju dosadašnje teze prema kojima slabije razvijene zemlje rastu brže od razvijenih, pod uvjetom konvergiranja prema zajedničkim stabilnim stanjima, tj. prema onim zemljama ili skupini zemalja s kojom dijele zajednička strukturna obilježja (razina tehnologije, stopa štednje, rast stanovništva itd.).

Pritom je potrebno sagledati i strukturu ukupnih ulaganja u istraživanje i razvoj, tj. ulaganja javnoga sektora, poslovnoga sektora, sektora visokoga obrazovanja i privatnoga neprofitnog sektora. Također, Fagerberg et al. (1997.) ističu kako se učinci ulaganja u istraživanje i razvoj ne mogu manifestirati u kratkome roku te naglašavaju važnost ulaganja poslovnoga sektora. Naime, takva ulaganja su usmjerena stvaranju inovacija, a koje se moraju implementirati i uspjeti na tržištu, a čime će izravno doprinijeti nacionalnoj konkurentnosti i gospodarskome rastu. Nadalje, Guelllec i Pottelsberghe (2001.) upućuju na učinke ulaganja poslovnoga sektora s gledišta prelijevanja te sposobnosti apsorpcije tehnologije iz inozemstva, javnoga sektora te sveučilišta. Stoga, u svrhu ostvarenja gospodarskoga rasta, države moraju otvoriti svoje granice te omogućiti slobodan pristup stranim tehnologijama te njihove produkte staviti u funkciju ostvarenja blagostanja (Damien et al. 2003.). Dabić (2007.) upućuje na manjak ulaganja poslovnoga sektora u aktivnosti istraživanja i razvoja te njihovu implementaciju na tržište, kao jedan od glavnih razloga zaostajanja EU za glavnim konkurentima (SAD, Kina, Južna Koreja itd.). Do sličnih zaključaka došlo se i analizom ulaganja poslovnoga sektora u Republici Hrvatskoj u procesu uključivanja u EU (Bečić i Dabić, 2008.). Također, autori kao ostale „slabe“ strane Republike Hrvatske ističu i nepovoljnu poziciju u globalnoj znanosti, tehnološko zaostajanje te slabu implementaciju znanstvenih produkata u poduzetnički i industrijski sektor, a što je prepoznato kao otežavajuća okolnost u prilagodbi gospodarstvu EU. Gotovo isti zaključci su prisutni u radovima Prodanovića et al. (2013.), Krstića i Đunića (2014.) te Švarca (2014.), koji uz Republiku Hrvatsku analiziraju stanje u ostalim zemljama regije (zemljama zapadnoga Balkana). Autori naglašavaju nisku razinu ulaganja u istraživanje i razvoj, nedovoljan angažman poslovnoga sektora te nedostatak suradnje sveučilišta i gospodarstva u procesu komercijalizacije inovacija. Nadalje, kao veliki problem istaknuta je zatvorenost samih znanstvenih sustava, tj. slaba mobilnost znanstvenika, nastavnoga i ostaloga osoblja te studenata, međunarodna disperzija rezultata istraživanja, kao i nedovoljna suradnja institucija s relevantnim međunarodnim partnerima. Navedeno je rezultiralo pojavom dva negativna procesa, tj. brain draina (odljeva mozgova) i brain vastea (napuštanja poslova u istraživačkome sektoru te odlazak na bolje plaćena radna mjesta). 


\section{ANALIZA GOSPODARSKOGA STANJA U REPUBLICI HRVATSKOJ}

Republika Hrvatska je ostvarivala konstantan rast BDP-a per capita do 2008. godine, kada pod teretom gospodarske krize započinje stagnacija ili smanjivanje vrijednosti, a koje je potrajalo do 2014. godine. U 2015. godini započinje ponovni rast, koji je nastavljen do 2016. godine, kada je Republika Hrvatska ostvarila BDP per capita od 11.000 eura. S druge strane, na razini EU prosječna razina BDP-a per capita je u 2016. godini iznosila 29.000 eura (grafikon 1.).

Grafikon 1. Kretanje BDP-a per capita (u eurima) u Republici Hrvatskoj i EU u razdoblju 2003. - 2016. godine

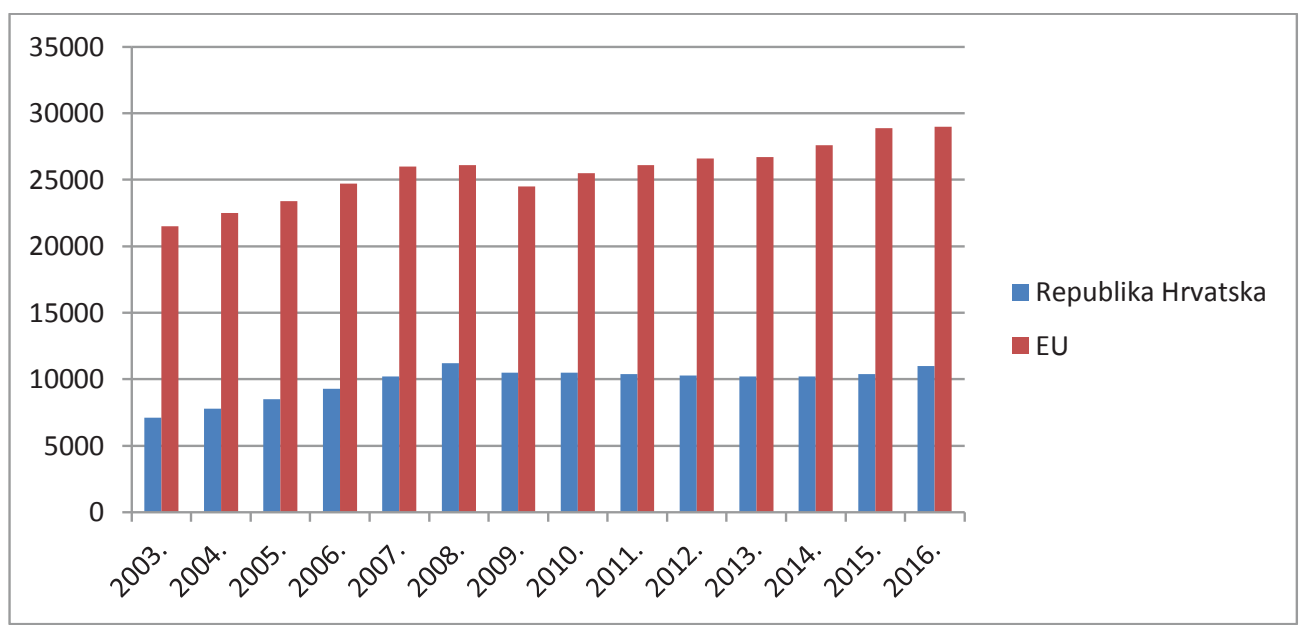

Izvor: izrada autora na temelju AMECO (1), 2016.

Sagledavanjem raspoloživih podataka, moguće je zaključiti kako je Republika Hrvatska ostvarila određeni napredak. Naime, na početku promatranoga razdoblja Republika Hrvatska se nalazila na 33,3 \% prosjeka EU. S druge strane, u 2016. godini, Republika Hrvatska se prema ovome pokazatelju nalazi na 37,9\% prosjeka EU. Ipak, ostvareni je napredak još uvijek nizak. Navedena situacija te relativno sporo „napredovanje“ u odnosu na razvijenije zemlje članice EU u promatranome razdoblju je prije svega rezultat negativnih učinaka svjetske gospodarske krize, kojom je Republika Hrvatska bila najjače pogođena od svih europskih zemalja. Također, relativno niske razine ,napredovanja“ proizlaze iz činjenice da je Republika Hrvatska do 2013. godine, kao zemlja kandidatkinja, bila „izvan“ sustava unutarnjeg EU tržišta, a što je ograničavalo iskorištavanje njegovih prednosti te ostvarivanje većih razina gospodarskoga rasta.

Analizirajući stope rasta BDP-a, vidljivo je kako je hrvatsko gospodarstvo tijekom cijeloga promatranog razdoblja raslo „brže“ od prosjeka EU, tj. prosječna stopa rasta hrvatskoga gospodarstva je u promatranome razdoblju iznosila $1,42 \%$, dok je ta vrijednost na razini EU iznosila 0,92 \% (grafikon 2.). 
Grafikon 2. Stope rasta BDP-a (\%) u Republici Hrvatskoj i EU u razdoblju 2003. - 2016. godine

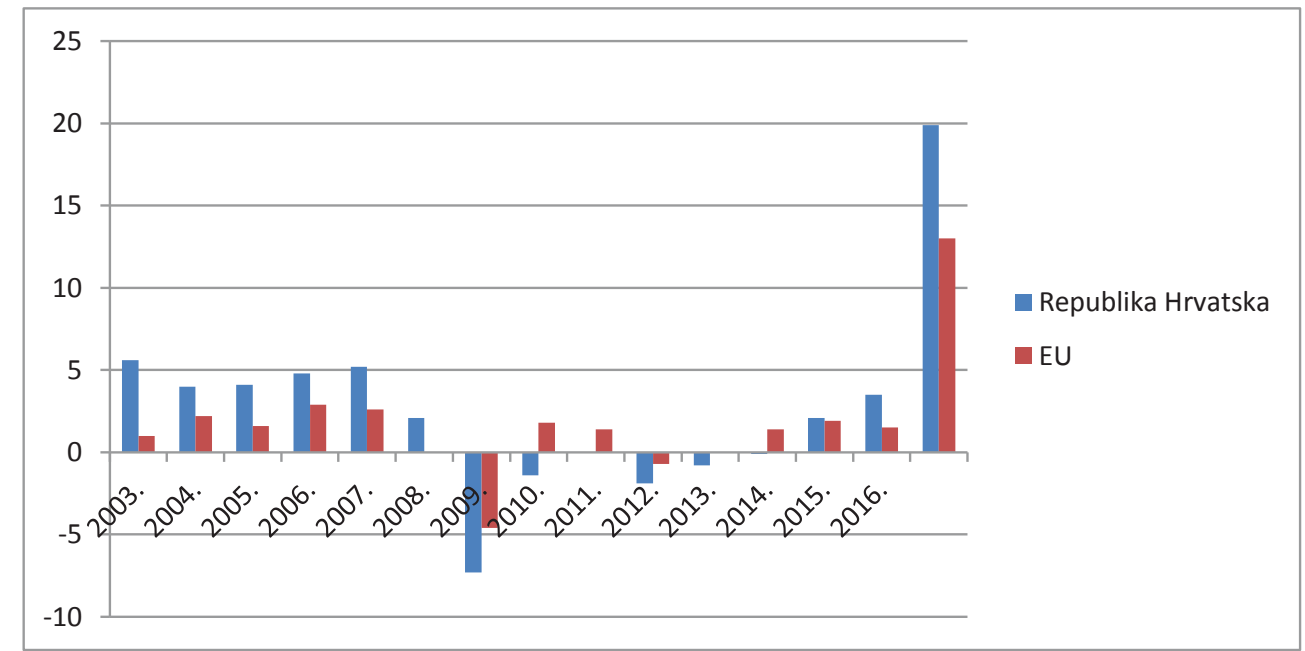

Izvor: izrada autora na temelju Eurostat (1), 2016.

Kao i kod analize BDP-a per capita, i u ovome slučaju vidljiv je vrlo jak utjecaj svjetske gospodarske krize na hrvatsko gospodarstvo. Naime, do početka globalne ekonomske krize, hrvatsko gospodarstvo je ostvarivalo prosječnu stopu rasta BDP-a od 4,3\%. Međutim, od 2009. godine započinje razdoblje stagnacije i izraženog usporavanja gospodarstva, a koje je potrajalo sve do 2015. godine, kada se javljaju prve naznake „novoga“ rasta. Temeljem dostupnih podataka moguće je zaključiti kako je hrvatsko gospodarstvo u razdoblju 2009. - 2016. godine ostvarivalo prosječno negativnu stopu gospodarskoga rasta, $\mathrm{tj}$. $-0,7 \%$ za cjelokupno razdoblje. Iz analize stopa gospodarskoga rasta Republike Hrvatske, vidljiva je opravdanost temeljne konvergencijske postavke, ,,prema kojoj slabije razvijene zemlje rastu brže od razvijenih“, a što je objašnjeno u Armstrong i Taylor (2000.) te Mankiew et al. (1992.).

Grafikon 3. Dodana vrijednost primarnoga, sekundarnoga i tercijarnoga sektora u BDP-u (\%) Republike Hrvatske, u razdoblju 2003. - 2015. godine

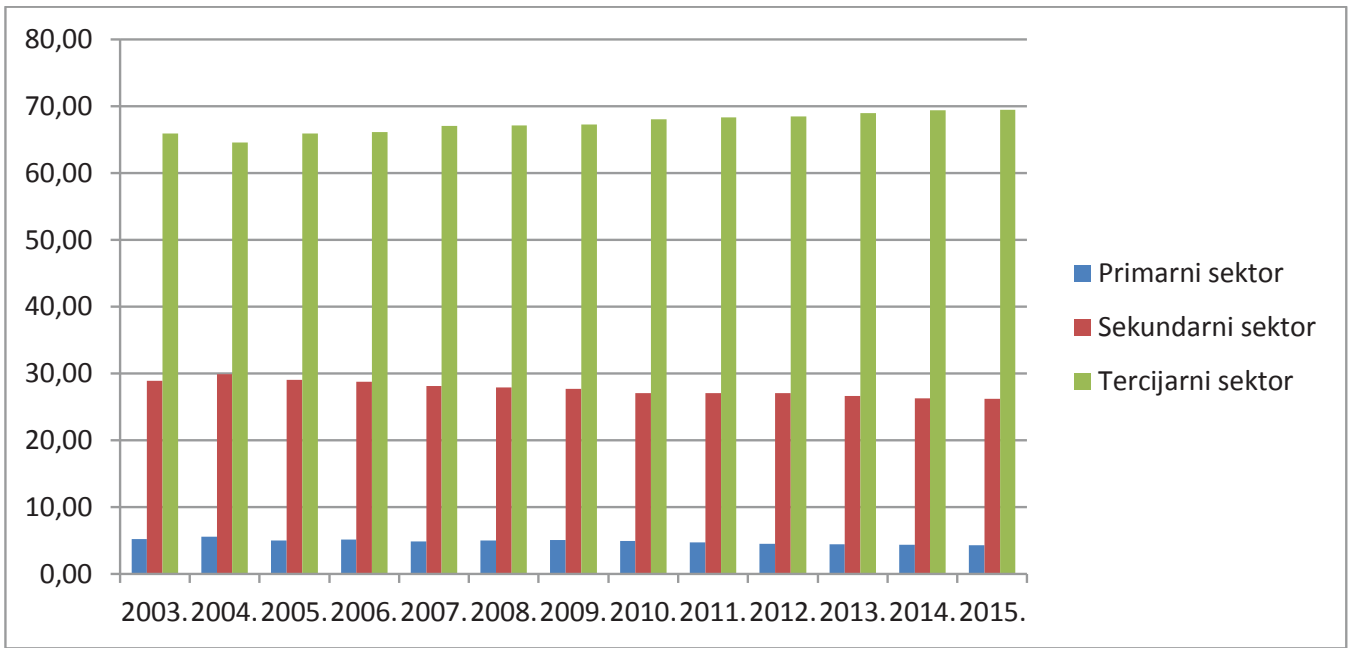

Izvor: izrada autora temeljem Svjetska banka (1), Svjetska banka (2), Svjetska banka (3), 2016. 
Gospodarsko stanje zemlje moguće je ocijeniti i temeljem dodane vrijednosti primarnoga, sekundarnoga i tercijarnoga sektora te njihove zastupljenosti u ukupnoj zaposlenosti. U ukupnoj strukturi hrvatskoga gospodarstva, najveću dodanu vrijednost ostvaruje tercijarni sektor $(69,5 \%)$, a nakon kojega slijede sekundarni sektor $(26,21 \%)$ te primarni sektor $(4,29 \%)$. Općenito, temeljem podataka moguće je utvrditi kako je hrvatsko gospodarstvo u promatranome razdoblju obilježeno smanjenjem udjela primarnoga i sekundarnoga sektora u BDP-u te povećanjem udjela tercijarnoga sektora (grafikon 3.).

Slična je situacija prisutna i na razini EU (grafikon 4.). Prema dostupnim pokazateljima, vidljivo je kao u EU primarni sektor ostvaruje 1,59 \% ukupne dodane vrijednosti, 24,41 $\%$ otpada na aktivnosti sekundarnoga sektora, dok, kao i na razini Republike Hrvatske, najveći dio otpada na aktivnosti tercijarnoga sektora (74\%).

Grafikon 4. Dodana vrijednost primarnoga, sekundarnoga i tercijarnoga sektora u BDP-u EU (\%), u razdoblju 2003. - 2015. godine

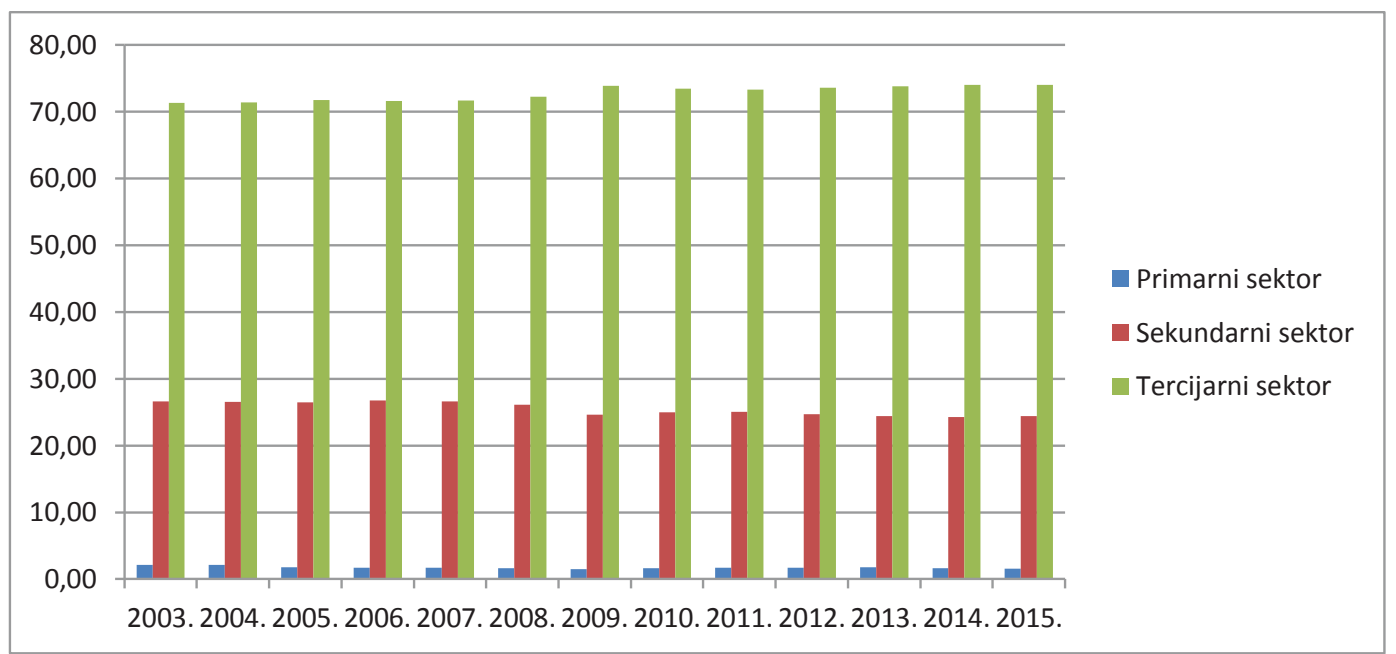

Izvor: izrada autora temeljem Svjetska banka (1), Svjetska banka (2), Svjetska banka (3), 2016.

Iz svega navedenoga, razvidno je kako EU i Republika Hrvatska prolaze kroz proces deindustrijalizacije, koji podrazumijeva smanjivanje udjela industrijske proizvodnje u ukupnome BDP-u te smanjivanje zaposlenosti u sekundarnome sektoru (Caincross, 1982. i Lever, 1991.). Također, na primjeru EU potvrđena je teza koja ističe kako je deindustrijalizacija prirodan proces, koji nastaje kao posljedica gospodarskoga rasta i promjena u gospodarskoj strukturi (Clark, 1957. i Kaldor, 1966.).

Usporednom analizom doprinosa pojedinih sektora ukupnome BDP-u, moguće je stvoriti određene zaključke o sadašnjemu položaju Republike Hrvatske. Naime, premda je ostvarila određena „poboljšanja“, Republika Hrvatska još uvijek ima relativno visoku zastupljenost primarnoga sektora $\mathrm{u}$ ukupnome BDP-u, $\mathrm{tj}$. njegova razina je gotovo tri puta veća od prosjeka EU. Problem hrvatske poljoprivrede proizlazi iz njezine „tradicionalnosti“, usmjerenosti na mala obiteljska gospodarstva te slabe međunarodne konkurentnosti. Kao takva, poljoprivreda ne može predstavljati čimbenik napretka i ostvarivanja rasta hrvatskoga gospodarstva. Nadalje, Republika Hrvatska još uvijek ostvaruje relativno visoke 
razine sekundarnoga sektora u BDP-u (26,21\%), a što je također (iako, ne osjetno) iznad prosjeka EU. Problem industrijskoga sektora u Republici Hrvatskoj također proizlazi iz usmjerenosti na tradicionalne sektore, slabu tehnološku orijentiranost te, kao posljedicu svega navedenog, nisku međunarodnu konkurentnost. U skladu sa suvremenim trendovima deindustrijalizacije i povezanih procesa, Republika Hrvatska bi se trebala usmjeriti prema ostvarivanju reindustrijalizacije, tj. razvoju industrije u izmijenjenim uvjetima, a koji zahtijevaju primjenu visokih tehnologija te usmjerenost na produkte znanja, u funkciji ostvarivanja međunarodne konkurentnosti.

Nadalje, grafikonom 5. i grafikonom 6. prikazana je zaposlenost u primarnome, sekundarnome i tercijarnome sektoru (\% ukupne zaposlenosti) u Republici Hrvatskoj i EU u razdoblju 2003. - 2014. godine.

Grafikon 5. Zaposlenost u primarnome, sekundarnome i tercijarnome sektoru (\% ukupne zaposlenosti) u Republici Hrvatskoj u razdoblju 2003. - 2014. godine

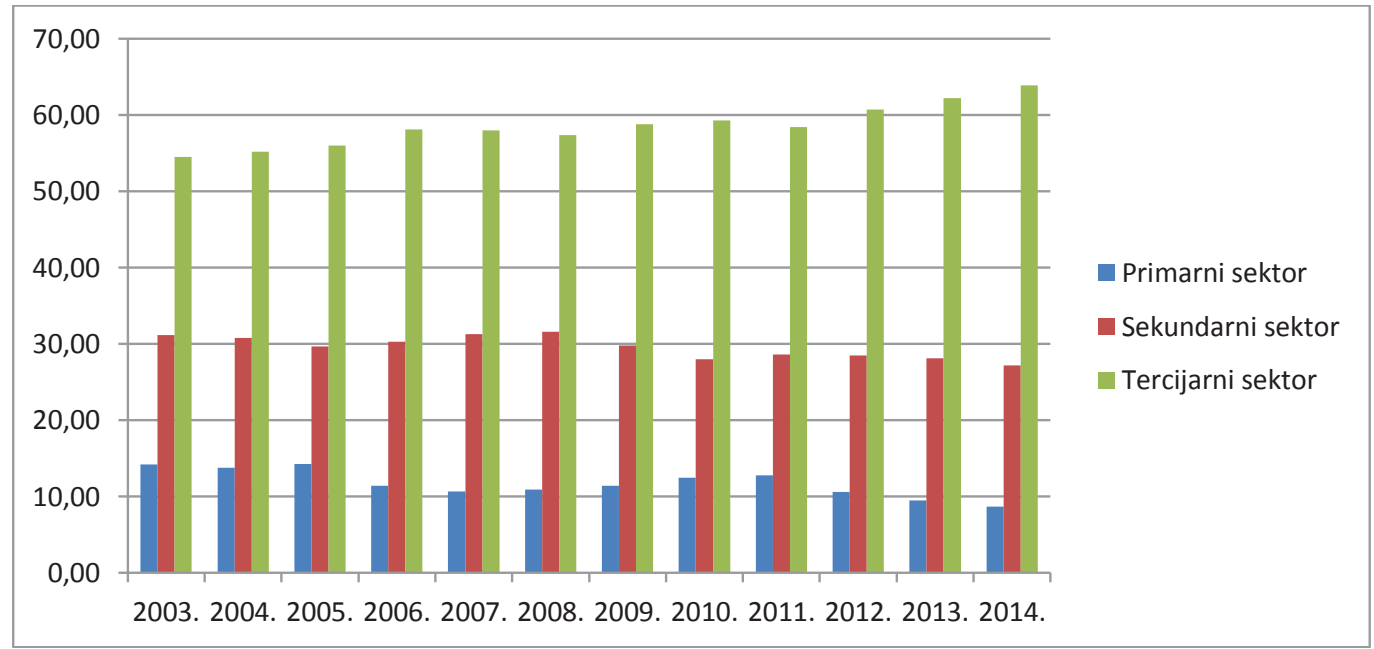

Izvor: izrada autora temeljem Svjetska banka (4), Svjetska banka (5), Svjetska banka (6), 2016.

Podaci o zaposlenosti u primarnome sektoru, upućuju kako se ona konstantno smanjivala do 2007. godine, kada započinje rast koji je potrajao do 2011. godine. Ponovno smanjivanje udjela poljoprivrede u ukupnoj zaposlenosti započinje 2012. godine te je potrajalo do 2014. godine, kada je ukupna zaposlenost u primarnome sektoru iznosila 8,7 \%. Slična situacija je prisutna i u sekundarnome sektoru, na koji otpada 27,2 \% ukupne zaposlenosti. Zaposlenost u tercijarnome sektoru se tijekom cjeloga promatranog razdoblja povećavala (osim u 2011. godini) te na nju otpada 63,9\% ukupne zaposlenosti. S druge strane, EU je u cijelome promatranom razdoblju ostvarivala smanjenje zaposlenosti u primarnome sektoru (osim u 2010. godini). Ukupna zaposlenost u primarnome sektoru je u 2014. godini iznosila 4,42\%. Nadalje, zaposlenost u sekundarnome sektoru se također konstantno smanjivala (iznimka je 2007. godina) te je u 2014. godini bila na razini $24,32 \%$. S druge strane, zaposlenost u tercijarnome sektoru bilježi rastuće vrijednosti, pri čemu je u 2014. godini iznosila 70,69\%. 
Grafikon 6. Zaposlenost u primarnome, sekundarnome i tercijarnome sektoru (\% ukupne zaposlenosti) u EU u razdoblju 2003. - 2014. godine

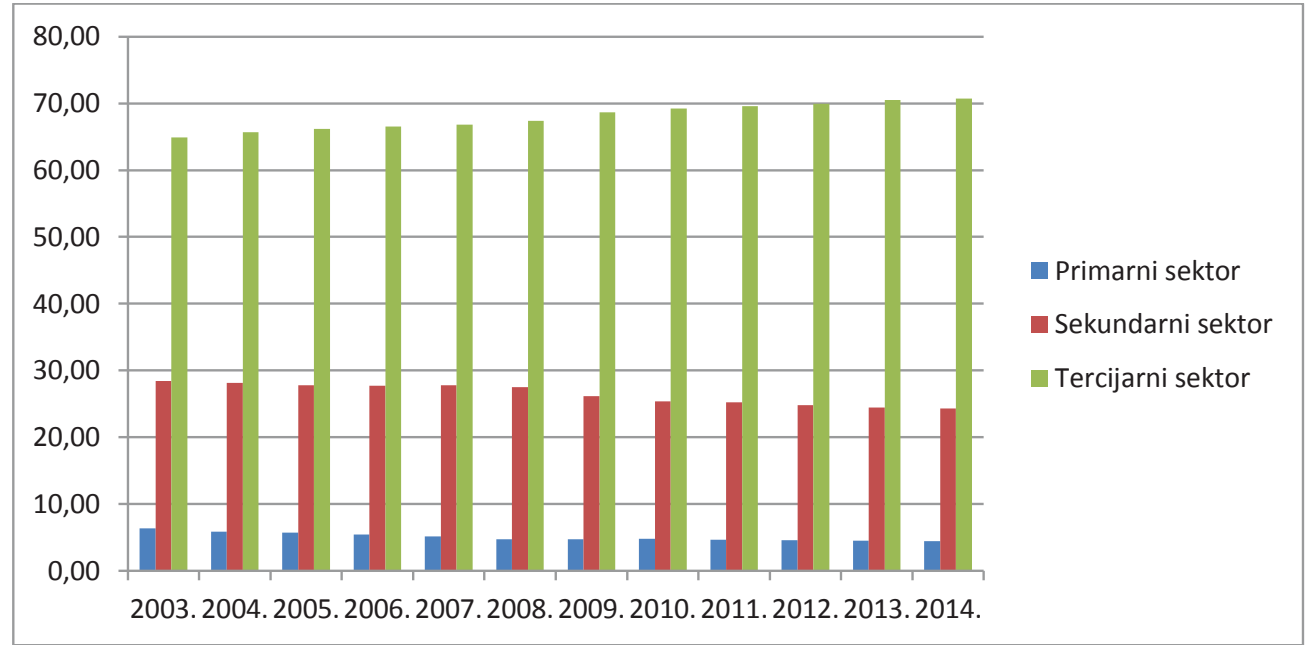

Izvor: izrada autora temeljem Svjetska banka (4), Svjetska banka (5), Svjetska banka (6), 2016.

Zaostajanje Republike Hrvatske u odnosu na EU je vidljivo i iz analizirane strukture zaposlenosti. Naime, Republika Hrvatska još uvijek ima relativno visoku zaposlenost $u$ primarnome sektoru, tj. gotovo dvostruko veću od EU prosjeka. Obilježje „,poljoprivredne“ radne snage je najčešće niska razina obrazovanosti, informatičke pismenosti te manjak posjedovanja ključnih znanja, potrebnih za prilagodbu promjenljivim suvremenim uvjetima. Također, stanovništvo ruralnih područja, a posebno mlado i obrazovano stanovništvo, uglavnom je nezainteresirano za nastavak obavljanja primarnih djelatnosti te se iseljava iz tih područja, čime se uzrokuje njegovo daljnje zaostajanje. Također, značajka ukupne poljoprivredne djelatnosti je, kao što je prethodno navedeno, usmjerenost na mala obiteljska

Grafikon 7. Kretanje nezaposlenosti (\% aktivnoga stanovništva) u Republici Hrvatskoj i EU u razdoblju 2003. - 2016. godine

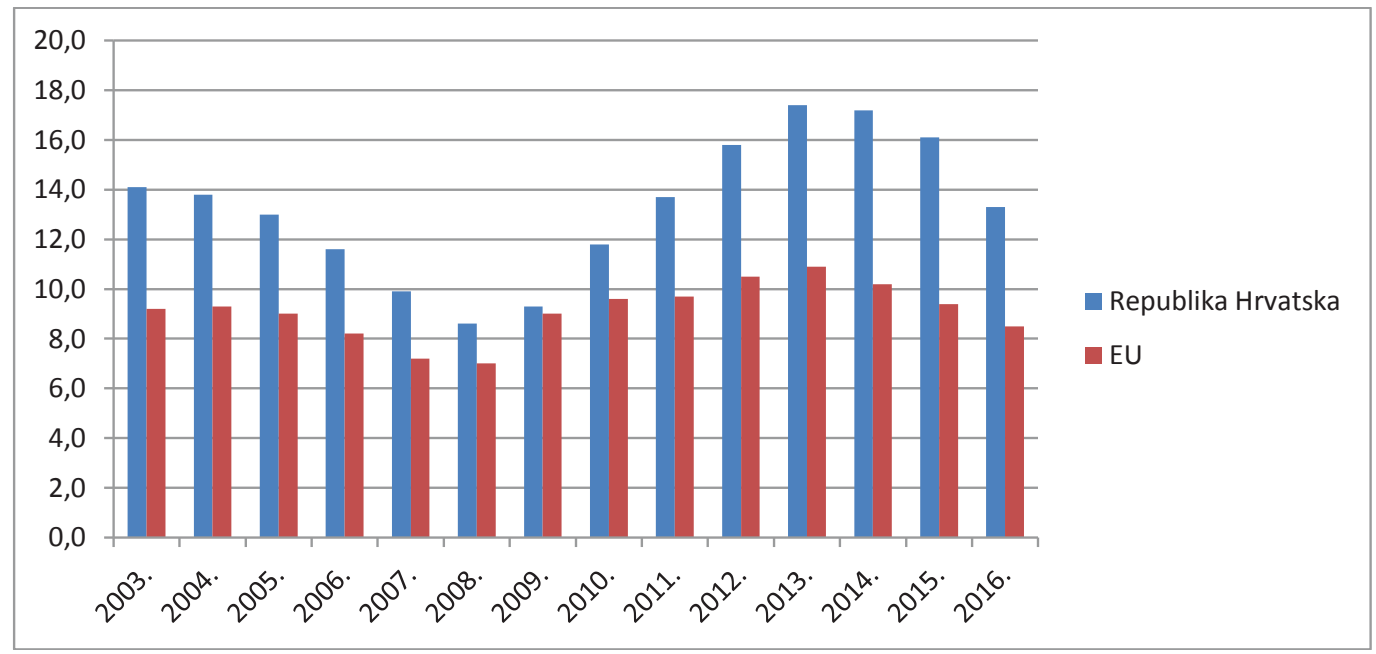

Izvor: izrada autora temeljem Eurostat (2), 2016. 
gospodarstva te proizvodnja, u većini slučajeva, samo za osobne potrebe. Stoga, postojeća struktura poljoprivrednoga stanovništva ne može predstavljati generator gospodarskoga oporavka i smanjenja zaostajanja Republike Hrvatske. Nadalje, sličan je problem prisutan i u sekundarnome sektoru, gdje Republika Hrvatska, unatoč smanjenju njegova udjela, još uvijek ostvaruje vrijednosti iznad EU prosjeka. Naime, i u sekundarnome sektoru prisutan je veliki broj niskokvalificiranih radnika, koji uslijed promjena u poslovanju i globalnome okruženju, ne mogu ,premjestiti“ svoje vještine na druga, naprednija radna mjesta te staviti svoja znanja u funkciju ostvarenja gospodarskoga rasta. Propadanje tradicionalnih industrijskih postrojenja rezultira otpuštanjem radnika koji nemaju mogućnosti prilagodbe, a što rezultira povećanjem nezaposlenosti te daljnjim pritiscima na proračun i ostale instrumente socijalnoga sustava. Upravo spomenuta nezaposlenost predstavlja jedan od najznačajnijih problema hrvatskoga gospodarstva, proizašao prije svega iz posljedica prethodne gospodarske krize (grafikon 7.).

Republika Hrvatska je tijekom posljednje gospodarske krize ostvarivala konstantan rast stope nezaposlenosti, pri čemu je najveća vrijednost dosegnuta u 2013. godini (17,4\%), nakon čega počinje smanjivanje koje je potrajalo do 2016. godine (13,3\%). S druge strane, na razini EU najveća stopa nezaposlenosti je također dosegnuta u 2013. godini (10,9\%), a nakon čega započinje smanjivanje. Trenutačno, Republika Hrvatska još uvijek ostvaruje osjetno više razine nezaposlenosti od EU prosjeka, tj. nezaposlenost u Republici Hrvatskoj je 1,5 puta veća. Uz nezaposlenost, čimbenik zaostajanja hrvatskoga gospodarstva predstavlja i niža razina zaposlenosti (15-64), u usporedbi s EU prosjekom. Stopa zaposlenosti stanovništva 15-64 je u Republici Hrvatskoj u 2016. godini iznosila 65,6 \%, a što predstavlja smanjenje u odnosu na 2015. godinu (66,9\%). S druge strane, zaposlenost na razini EU je u stalnome porastu te je u 2016. godini dosegnula razinu od $73 \%$.

Grafikon 8. Kretanje zaposlenosti (\% aktivnoga stanovništva, 15-64 godine) u Republici Hrvatskoj i EU u razdoblju 2003. - 2016. godine

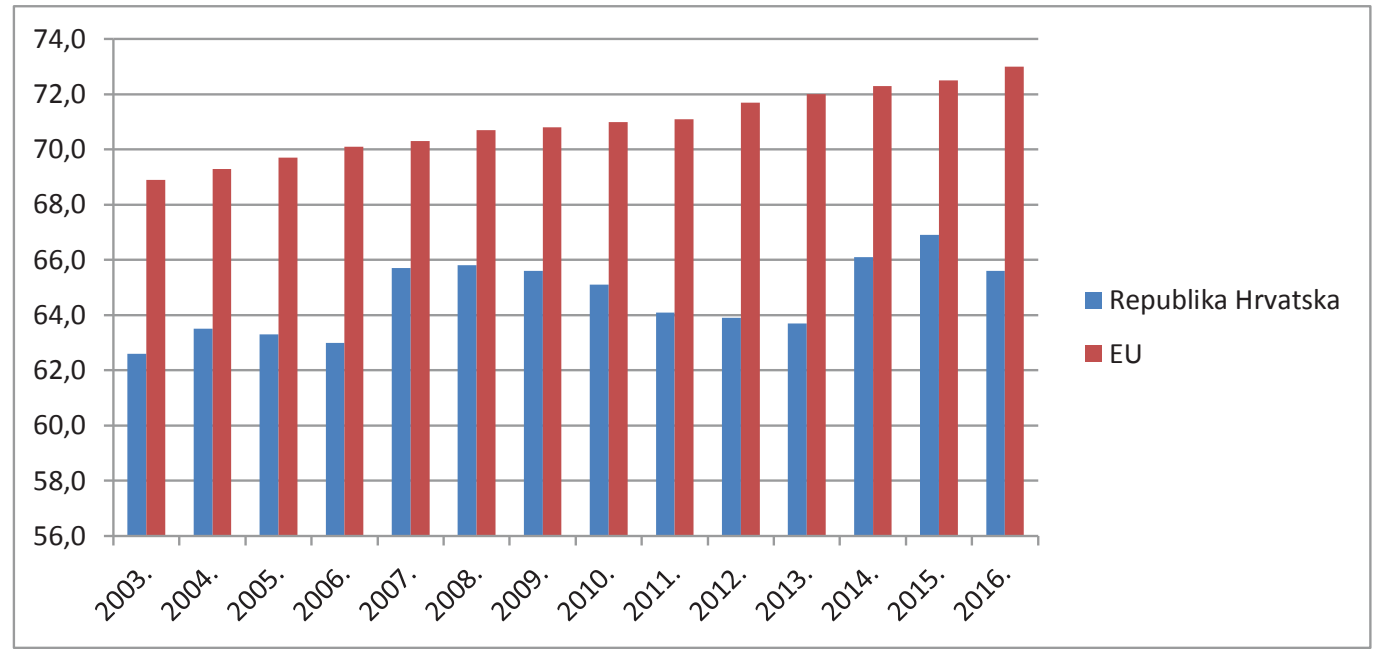

Izvor: izrada autora temeljem Eurostat (2), 2016.

Analizom gospodarskoga stanja u Republici Hrvatskoj, utvrđena su značajna zaostajanja gospodarstva u usporedbi s prosjekom EU. Pritom, kao najveće probleme potrebno je 
istaknuti niske razine BDP-a per capita, visoke stope nezaposlenosti, niske stope zaposlenosti te relativno nepovoljnu strukturu BDP-a i zaposlenosti. Navedena situacija predstavlja izazov u daljnjemu ostvarivanju gospodarskoga napretka te ostvarenja održivoga članstva u EU. Pritom se kao najvažniji izvori budućega gospodarskog rasta, kako u teoriji, tako u ključnim razvojnim strategijama, ističu ulaganja u istraživanje i razvoj i njihovi produkti. Uzimajući u obzir sve navedeno, Republika Hrvatska treba ojačati aktivnosti implementacije ekonomije znanja. Ipak, istraživanja provedena u nastavku rada upućuju na značajna zaostajanja i u tome području.

\section{ANALIZA ULAGANJA U ISTRAŽIVANJE I RAZVOJ U REPUBLICI HRVATSKOJ}

Ulaganja u istraživanje mjerena udjelom u BDP-u su se u Republici Hrvatskoj povećavala do 2008. godine, kada je dosegnuta razina od 0,88 \% BDP-a, a što predstavlja najveću razinu u promatranome razdoblju. Gospodarska kriza je imala utjecaj i na ovaj dio gospodarske aktivnosti, budući da podaci upućuju na smanjenje ulaganja u istraživanje u razvoj u vrijeme gospodarske krize. Ponovno povećanje započinje u 2014. godini i nastavljeno je do 2015. godine, kada su ulaganja u istraživanje i razvoj iznosila $0,85 \%$ BDP-a (grafikon 9.).

Grafikon 9. Ulaganja u istraživanje i razvoj (\% BDP-a) u Republici Hrvatskoj i EU u razdoblju 2003. - 2015. godine

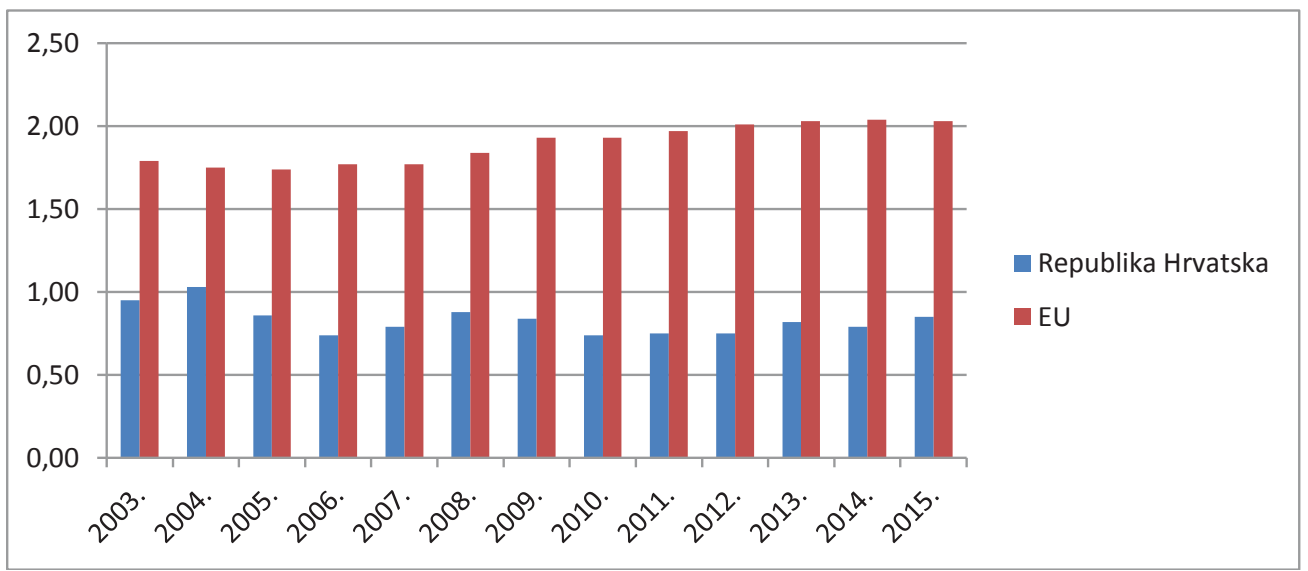

Izvor: izrada autora temeljem Eurostat (3), 2016.

S druge strane, na razini EU ukupna ulaganja u istraživanje i razvoj iznose 2,03\% BDP-a u 2015. godini, a što predstavlja neznatno smanjenje u usporedbi s 2014. godinom. Analizom je moguće utvrditi osjetna zaostajanja Republike Hrvatske u usporedbi s EU. Naime, trenutačno Republika Hrvatska ostvaruje 2,3 puta manja ulaganja u istraživanje i razvoj od prosjeka EU, a čime se ona nalazi na 41,8 \% EU. Također, osjetna zaostajanja su vidljiva i prema ulaganjima u istraživanje i razvoj po glavi stanovnika. Naime, Republika Hrvatska je u 2015. godini ulagala otprilike 88,7 eura po stanovniku, dok je ta vrijednost na razini EU iznosila 587,7 eura. 
Jasniju sliku o ulaganjima u istraživanje i razvoj moguće je dobiti analizom ključnih sektora financiranja. Pritom su analizirana ulaganja javnoga sektora, poslovnoga sektora te sektora visokoga obrazovanja mjerena udjelom u BDP-u (grafikon 10.).

Grafikon 10. Struktura ulaganja u istraživanje i razvoj u Republici Hrvatskoj u razdoblju 2003. - 2015. godine (\% BDP-a)

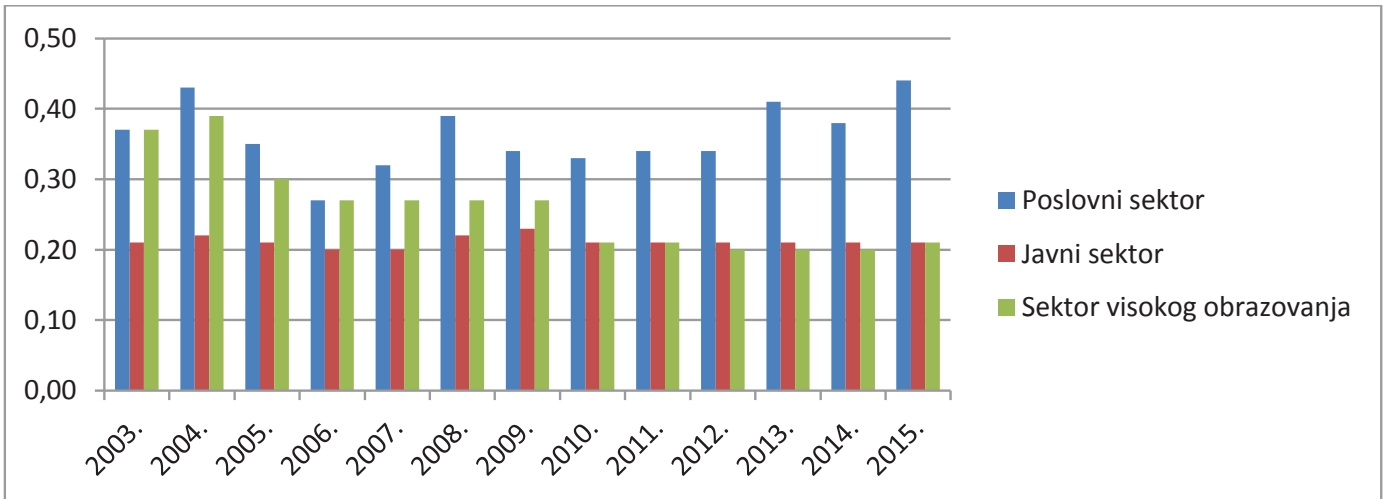

Izvor: izrada autora temeljem Eurostat (4), 2017.

U strukturi ukupnih ulaganja u istraživanje i razvoj u Republici Hrvatskoj prevladava poslovni sektor, a na koji otpada $0,44 \%$ BDP-a. Nadalje, podjednake vrijednosti ostvaruju javni sektor $(0,21 \%$ BDP-a) te sektor visokog obrazovanja (0,21 \% BDP-a). Međutim, usporedbom s prosjekom EU, i u ovome su području prisutna zaostajanja. Naime, poslovni sektor na razini EU ulaže prosječno 1,3 \% BDP-a u aktivnosti istraživanja i razvoja, a što je 3 puta više nego od razine Republike Hrvatske. Međutim, kao „olakotnu“ okolnost u ovome slučaju je potrebno uzeti nepovoljno okruženje hrvatskih poduzeća, obilježeno prije svega

Grafikon 11. Obrazovna struktura stanovništva Republike Hrvatske u razdoblju 2003. - 2016. godine (\% stanovništva 15-64 godine)

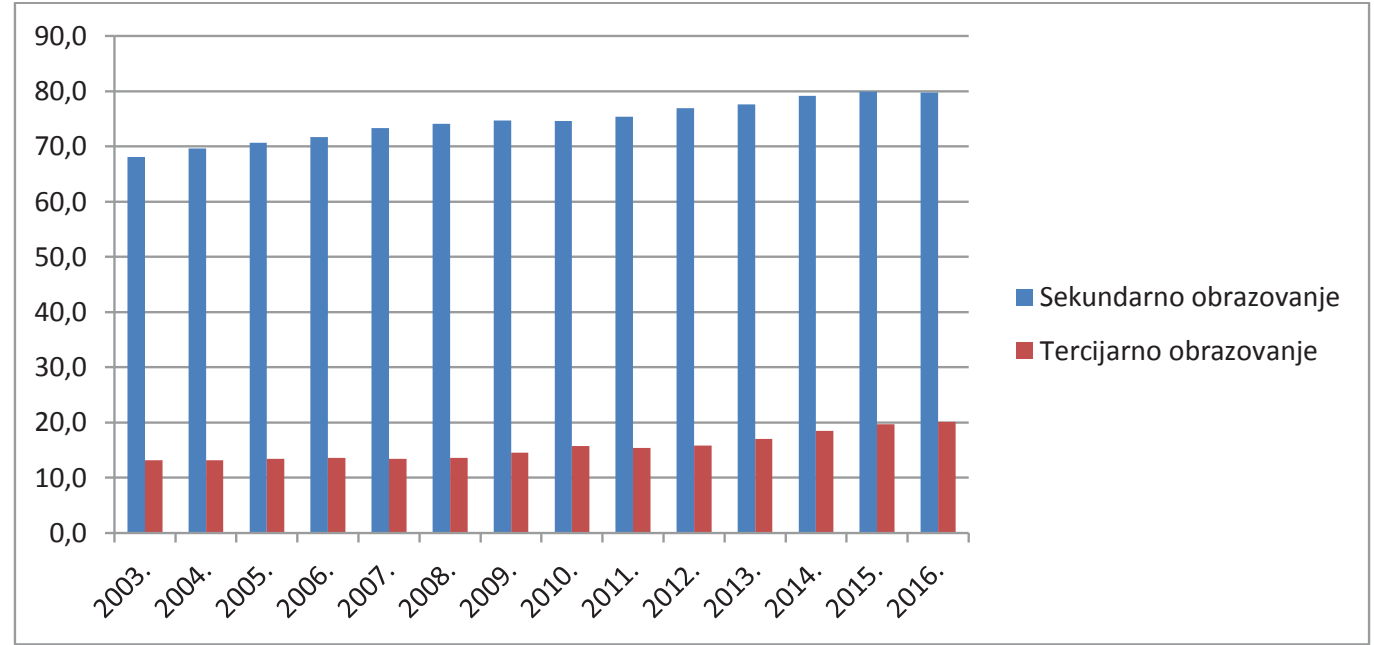

Izvor: izrada autora temeljem Eurostat (5), 2017. 
kompleksnim administrativnim okruženjem, visokim fiskalnim nametima i korupcijom, a koja uvelike ograničava njihove daljnje inovativne aktivnosti. Nadalje, Republika Hrvatska, a što je značajka i ostalih zemalja sličnih obilježja, veliki udio ulaganja u znanstveno-istraživačke djelatnosti ostvaruje iz javnih izvora. S druge strane, ulaganja sektora visokog obrazovanja su za gotovo $50 \%$ niža od prosjeka EU. Upravo na tim ulaganjima te njihovoj učinkovitoj tržišnoj implementaciji, a sukladno mišljenjima relevantnih teoretičara počiva budući razvoj gospodarstva.

Nadalje, potrebno je sagledati i obrazovnu strukturu stanovništva Republike Hrvatske. Kao osnovni pokazatelji su analizirani udio stanovništva 15-64 godine starosti, sa završenim srednjoškolskim, tj. visokoškolskim (tercijarnim obrazovanjem) (grafikon 11.).

U Republici Hrvatskoj 79,8 \% stanovništva 15-64 godine ima završeno sekundarno obrazovanje, čime je dostignuta i prestignuta razina EU (73 \%). S druge strane, 20,1 \% stanovništvo ima završeno tercijarno obrazovanje, a čime se Republika Hrvatska nalazi ispod prosjeka EU (27,2 \%). Ipak, jedan od najvećih problema obrazovnoga sustava u Republici Hrvatskoj predstavlja njegova slaba usklađenost s potrebama tržišta rada. Naime, veliki broj mladoga stanovništva nakon završenoga visokoškolskog obrazovanja ne može naći posao u svojoj struci, a što ih prisiljava na zapošljavanje u drugim sektorima i područjima djelatnosti ili iseljavanje iz Republike Hrvatske. Važan pokazatelj kvalitete sustava obrazovanja u pojedinoj zemlji te intencije prema ostvarenju društva znanja je i broj novih doktora znanosti na 1.000 stanovnika. Taj pokazatelj je među novim zemljama članicama EU najveći u Slovačkoj $(1,9)$, a visoke razine ostvaruju i Rumunjska $(1,7)$, Češka $(1,6)$ te Hrvatska i Estonija (1,4). S druge strane, najniže razine ostvaruju Cipar $(0,2)$, Malta $(0,3)$ i Bugarska $(0,6)$. Nadalje, unatoč nepovoljnoj situaciji u obrazovanju te nemogućnosti pronalaženja odgovarajućeg radnog mjesta te osiguranja egzistencije, u Republici Hrvatskoj još uvijek vrlo mali broj ljudi sudjeluje u programima cjeloživotnoga obrazovanja (grafikon 12.).

Grafikon 12. Sudjelovanje u programima cjeloživotnoga obrazovanja (\% stanovništva 25-64 godine) u razdoblju 2004. - 2016. godine

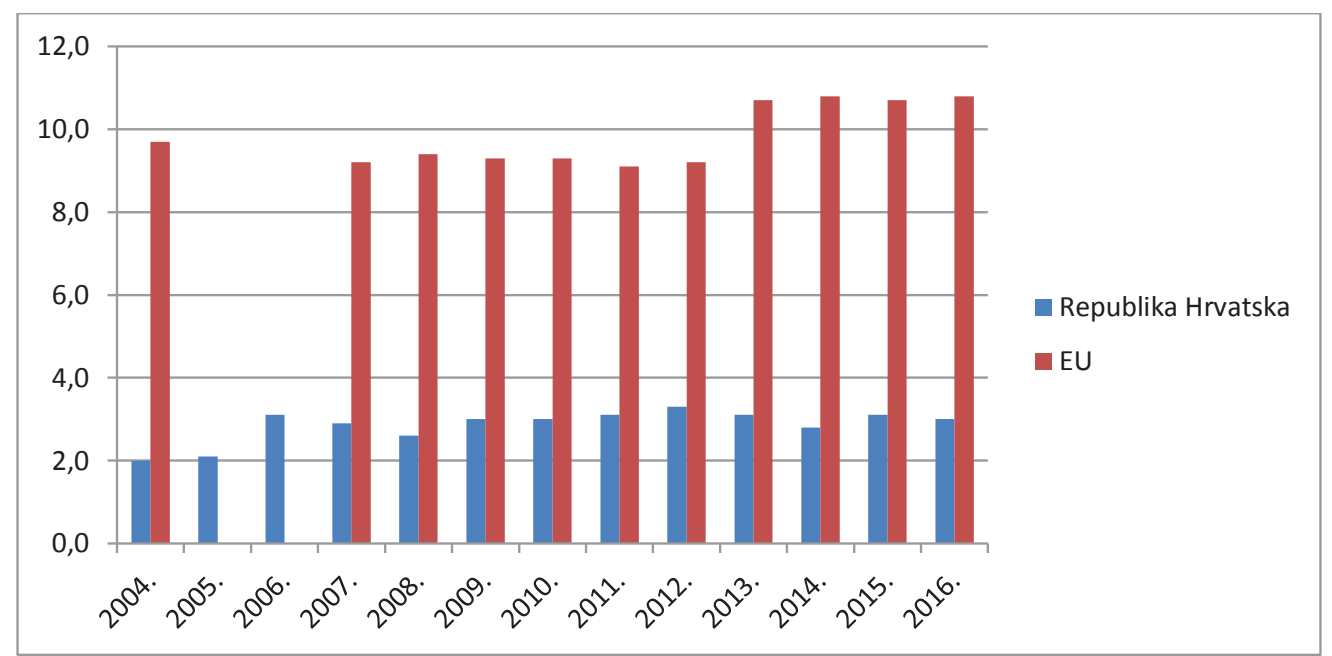

Izvor: izrada autora temeljem Eurostat (6), 2017. 
Naime, u Republici Hrvatskoj u programima cjeloživotnoga obrazovanja sudjeluje svega $3 \%$ stanovništva 25-64 godine, dok je na razini EU navedena vrijednost 3 puta veća $(10,8 \%)$. Navedeno također ukazuje na situaciju u Republici Hrvatskoj, u kojoj je ekonomija znanja proklamirana kao ključan cilj, ali njezina realizacija se još uvijek nalazi na vrlo niskim razinama. Pritom, upravo obrazovanje te kontinuirano usavršavanje radne snage predstavljaju ključan čimbenik ostvarenja napretka. Ocjena ulaganja u istraživanje i razvoj u pojedinoj zemlji je moguća i temeljem broja istraživača na milijun stanovnika. Na razini EU, na milijun stanovnika je u 2015. godini „djelovalo“ 3.426 istraživača. Među novim zemljama članicama EU, najveće razine ostvaruje Slovenija (4.216), a nakon koje slijede Estonija (3.338) te Češka (3.249). Republika Hrvatska se nalazi na samome dnu ove skupine zemalja (1.528), odmah nakon Cipra (775) i Rumunjske (944).

Nadalje, ulaganja u istraživanje i razvoj i njihovi produkti su prepoznati kao ključ ostvarivanja konkurentnosti na međunarodnoj razini, a pri čemu je $u$,središte pozornosti“ stavljen čovjek, tj. njegov intelektualni kapital, a koji bi trebao biti implementiran u funkciju ostvenja daljnjega napretka i pokretanja promjena. Stoga, nova tehnološka dostignuća, a koja se očituju kroz unaprjeđenje proizvodnih i organizacijskih procesa u poduzećima, potaknut će stvaranje i izvoz proizvoda visoke tehnologije. Analizom izvoza proizvoda visoke tehnologije, također je vidljivo zaostajanje Republike Hrvatske. Naime, u ukupnome izvozu prerađivačke industrije, na proizvode visoke tehnologije otpada $8,98 \%$, dok je navedena vrijednost na razini EU dvostruko veća (16,86 \%) (grafikon 13.).

Grafikon 13. Udio proizvoda visoke tehnologije u ukupnome izvozu prerađivačke industrije u Republici Hrvatskoj i EU u razdoblju 2003. - 2016. godine (\%)

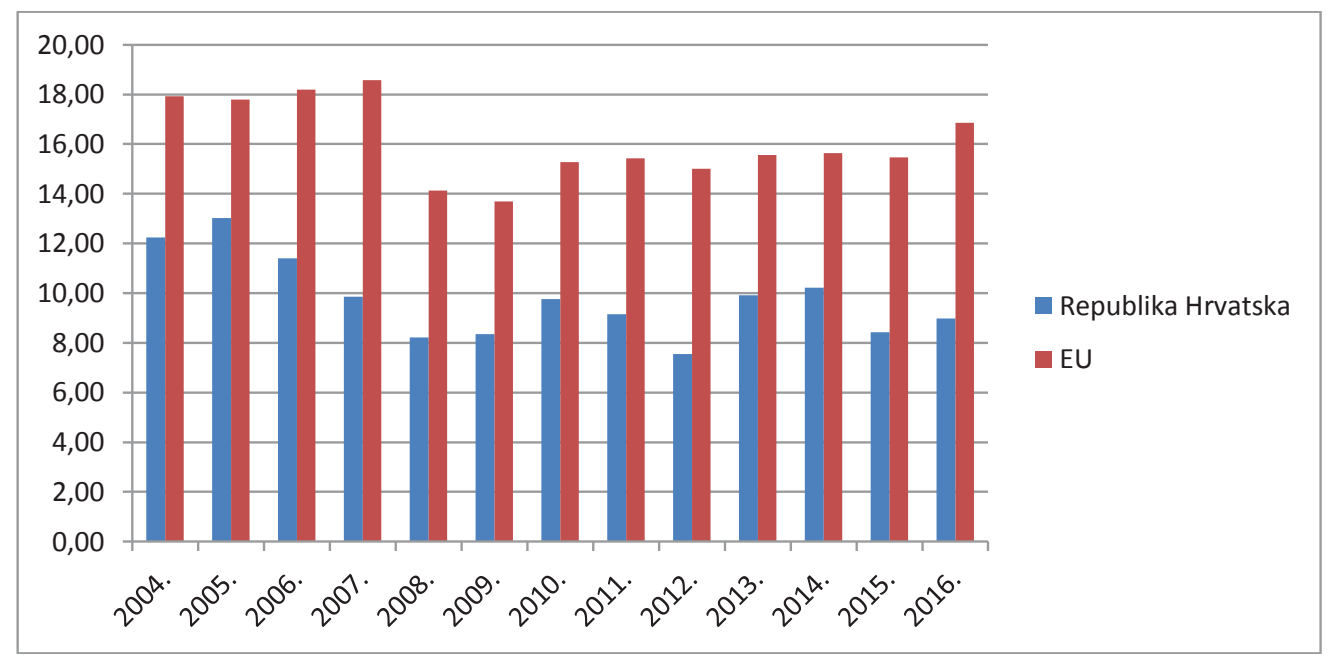

Izvor: izrada autora temeljem Svjetska banka (7), 2016.

Analizom ključnih pokazatelja ulaganja u istraživanje i razvoj, utvrđeno je značajno zaostajanje Republike Hrvatske za razinama u EU. Pritom, kao najveći problemi su prepoznati nedovoljan angažman poslovnoga sektora, neusklađenost obrazovnih sustava i potreba tržišta rada, nedostatak svjesnosti građana o potrebi stalnoga usavršavanja te upitna implementacija postojećih i raspoloživih znanstveno-tehnoloških resursa u ostvarenje globalne konkurentnosti, posebno putem izvoza proizvoda visoke tehnologije. Cjelokupna 
situacija u sektoru istraživanja i razvoja predstavlja problem, ali i izazov, pri čemu se kao ključno pitanje postavljaju mogućnosti unaprjeđenja te ubrzanje implementacije ekonomije znanja. Republika Hrvatska ima na raspolaganju veliki broj financijskih izvora te instrumenata propisanih nacionalnim i europskim razvojnim strategijama. Njihova učinkovita implementacija će uvelike ovisiti o stvaranju stabilnoga okruženja (poslovnoga, političkoga i društvenoga), koje će biti sposobno pratiti suvremene trendove te apsorbirati raspoloživa financijska sredstva i ostale prateće instrumente.

\section{PERSPEKTIVE OSTVARENJA GOSPODARSKOGA RASTA REPUBLIKE HRVATSKE TEMELJENE NA SUVREMENIM EKONOMSKIM RESURSIMA}

Ostvarenjem punopravnoga članstva u EU, Republika Hrvatska se obvezala implementirati odredbe strategije EUROPA 2020. Naime, EUROPA 2020 je desetogodišnja, temeljna razvojna strategija EU, čiji je ključni cilj ,stvoriti od Europe najbržerastuće i najkonkurentnije gospodarstvo svijeta temeljeno na znanju u razdoblju do 2020. godine.“ Pritom, Strategija je usmjerena na ostvarivanje 3 najznačajnija prioriteta, tj. pametnoga, održivoga i uključivoga rasta. Pametan rast podrazumijeva razvoj gospodarstva temeljenoga na znanju i inovacijama, održiv rast teži ostvarenju gospodarstva koje učinkovito koristi resurse, dok je uključiv rast usmjeren ka postizanju visokih stopa zaposlenosti, u funkciji ostvarenja društvene i teritorijalne kohezije (www.mobilnost.hr, 2015.). Također, u uskoj vezi s ključnim prioritetima, određeni su i najvažniji kvantitativni ciljevi, i to (Europska komisija, 2015.): 1) ostvarenje zaposlenosti veće od 75 \% (stanovništvo starosne dobi 25-64 godine), 2) ulaganja u istraživanje i razvoj od $3 \%$ BDP-a, 3) smanjenje emisija stakleničkih plinova za $20 \%$ (ili $30 \%$ ako postoje uvjeti) u odnosu na razinu iz 1990. godine, 4) dobivanje $20 \%$ ukupne energije iz obnovljivih izvora te povećanje energetske učinkovitosti za $20 \%$, 5) smanjenje stope ranog napuštanja školovanja na razinu ispod $10 \%, 6)$ povećanje udjela osoba od 30-34 godine sa završenim tercijarnim obrazovanjem na $40 \%$ te 7) smanjenje broja osoba koje žive pri riziku od siromaštva i socijalne isključenosti za barem 20 milijuna. Propisani ciljevi ne podrazumijevaju podjelu tereta, $\mathrm{tj}$. ovdje se radi o zajedničkim ciljevima koje je potrebno ostvariti kombinacijom djelovanja na nacionalnoj razini i razini EU.

Također, u svrhu ostvarenja ključnih prioriteta, EU je definirala 7 ključnih inicijativa (Europska komisija, 2015.). Pritom, za ostvarenje pametnoga rasta su predviđene: 1) Inovacijska unija - poticanje ulaganja u inovacije te jačanje inovacijskoga lanca, 2) Pokretanje mladih - unaprjeđenje obrazovnih sustava te lakša integracija na tržište rada te 3) Digitalna agenda za Europu - široka upotreba informacijsko-komunikacijskih tehnologija i rasprostranjenost brzoga interneta. Nadalje, za ostvarenje uključivoga rasta su definirane: 1) Agenda za nova radna mjesta - zapošljavanje, osposobljavanje te modernizacija tržišta rada te 2) Europska platforma protiv siromaštva - socijalna i teritorijalna kohezija te uključenost. Na kraju, prioritet održivoga rasta ostvaruje se kroz: 1) Resursno učinkovitu Europu - borba protiv klimatskih promjena te čista $i$ učinkovita energija te 2) Industrijsku politiku globalizacijskoga doba - stvaranje boljega poslovnog okruženja i jačih temelja industrije uz osiguranje veće razine konkurentnosti. 
Uz strategiju EUROPA 2020 i njezine mjere i instrumente, zemljama članicama EU je u svrhu ostvarivanja razvojnih ciljeva i implementacije ekonomije znanja, u razdoblju 2014. - 2020. godine dostupan i program OBZOR 2020, čiji proračun za navedeno razdoblje iznosi 78,6 milijardi eura. Općenito, Program objedinjuje aktivnosti Sedmog okvirnog istraživačkog programa, inovacijske aspekte Programa za konkurentnost i inovacije (CIP) te predstavlja doprinos Europskom institutu za inovacije i tehnologiju (EIT). Nadalje, OBZOR 2020 je stvoren kao izravni doprinos ostvarenju ciljeva EU vezanih za istraživanje i tehnološki razvoj, prioriteta EUROPA 2020 i Unije inovacija te kao pomoć u izgradnji Europskog istraživačkog prostora. Kao ključni prioriteti programa su određeni Izvrsna znanost, Industrijsko vodstvo te Društveni izazovi (OBZOR 2020, 2017.).

Također, na razini Republike Hrvatske definirano je nekoliko strategija, koje u središte stavljaju ulaganja u istraživanje i razvoj i njihove produkte, kao važan čimbenik ostvarenja napretka i poboljšanja međunarodne konkurentnosti hrvatskoga gospodarstva.

Ministarstvo gospodarstva $\mathrm{RH}$ je definiralo Strateški plan za razdoblje 2016. 2018. godine, usmjeren povećanju BDP-a, proizvodnje i zaposlenosti, temeljeno na kreiranju novih industrijskih proizvoda, razvoju inovacija, novih tehnologija i usluga s većom dodanom vrijednosti; povećanju izvoza i poticanju ulaganja. Pritom, kao najvažniji ciljevi su određeni: 1) Konkurentno i učinkovito, na znanju utemeljeno gospodarstvo prilagođeno gospodarskom okruženju Europske unije, 2) Razvoj i poticanje gospodarstva kroz poticanje investicija, unapređenje konkurentnosti industrije, jačanje energetskog sustava i gospodarenja mineralnim sirovinama, 3) Stvaranje preduvjeta za gospodarski rast uz osiguranje ravnopravne tržišne utakmice za sve gospodarske subjekte te 4) Razvoj i standardizacija trgovine $i$ unutarnjeg tržišta. Što se tiče ulaganja u istraživanje i razvoj, Plan predviđa dostizanje razina od 0,94 \% BDP-a do 2017. godine, tj. 0,98 \% BDP-a do 2018. godine (Ministarstvo znanosti obrazovanja i športa, 2017.).

Strategija poticanja investicija u Republici Hrvatskoj u razdoblju 2014. - 2020. godine određuje državne potpore za istraživanje i razvoj (u obliku državnih subvencija ili poreznih poticaja) te ističe ključna područja njihova usmjeravanja: (1) temeljna istraživanja, (2) primijenjena istraživanja i (3) razvojna istraživanja (Ministarstvo gospodarstva, poduzetništva i obrta (1), 2017.).

Inovacijska strategija Republike Hrvatske je definirana 2014. godine, kako bi se izgradio učinkovit inovacijski sustav koji će usmjeriti hrvatsko gospodarstvo prema aktivnostima koje su utemeljene na znanju, ali i kako bi se iskoristio potencijal Hrvatske obzirom na teritorijalni položaj, resurse te tradiciju u industrijskoj proizvodnji, ali i sposobnosti za inovativnost i kreativnost kao osnovne čimbenike pokretanja gospodarstva.

Kao najvažniji ciljevi Strategije, čije je ostvarenje planirano do 2020. godine, određeni su: 1) ulaganje u istraživanje od 1,4\% BDP-a, 2) ulaganja poslovnoga sektora u aktivnosti istraživanja i razvoja od 0,7\% BDP-a, 3) usmjeravanje $33 \%$ ukupnih znanstveno-istraživačkih ulaganja u investicijske projekte, 4) povećanje broja patentnih prijava na milijun stanovnika na 25, 4) $25 \%$ doprinosa stranih investitora ulaganjima u poslovnome sektoru te 5) povećanje broja istraživača u ukupnome broju zaposlenih u gospodarstvu na 1571 (Ministarstvo gospodarstva, poduzetništva i obrta (2), 2017.).

Nadalje, Vlada Republike Hrvatske je 2016. godine usvojila Strategiju pametne specijalizacije za razdoblje 2016. - 2020. godine, a kojom se hrvatskim subjektima otvara 
pristup sredstvima iz Europskih strukturnih i investicijskih fondova, namijenjenih jačanju istraživanja, tehnološkoga razvoja i inovacija (Tematski cilj 1), u iznosu od 664 milijuna eura. Cilj implementacije ovih programa je daljnje jačanje i napredak konkurentnosti hrvatskoga gospodarstva, upravo kroz istraživanje, inovacije i tehnološki razvoj. Kao ključna tematska područja Strategije određeni su: 1) Zdravlje i kvaliteta života, 2) Energija i održivi razvoj, 3) Promet i mobilnost, 4) Sigurnost te 5) Hrana i biokemija. Također, kao krajnji ciljevi Strategije određeni su ostvarenje gospodarskoga rasta, poticanje ulaganja poslovnoga sektora u aktivnosti istraživanja i razvoja te otvaranje novih, visokokvalificiranih radnih mjesta, uz jačanje suradnje znanstveno-istraživačkoga i poslovnoga sektora (Ministarstvo gospodarstva, poduzetništva, rada i obrta (3), 2017.). Strategija, uz prethodno navedene deskriptivne ciljeve, određuje i veliki broj kvantitativnih ciljeva, a među kojima je potrebno izdvojiti: 1) povećanje ulaganja poslovnoga sektora u aktivnosti istraživanja i razvoja na razinu od 0,7\% BDP-a do 2023. godine, 2) povećanje broja istraživača zaposlenih u poslovnome sektoru na 1.571 do 2023. godine, 3) ostvarenja udjela inovativnih malih i srednjih poduzeća u ukupnome broju malih i srednjih poduzeća od $35 \%$ te 4) ostvarenje izvoza proizvoda srednje $i$ visoke tehnologije (\% ukupnoga izvoza proizvoda) od 41,36\% do 2023. godine.

Temeljem analiziranih strategija, u nastavku rada je predložen autorski koncept budućega razvoja Republike Hrvatske. Pritom, kao ključne komponente su određeni povećanje ulaganja u istraživanje i razvoj, reforma obrazovnoga sustava, povezivanje sveučilišta $i$ gospodarstva te internacionalizacija cjelokupnoga znanstvenog sustava (slika 1.).

Slika 1. Komponente budućega „pametnog“ razvoja Republike Hrvatske

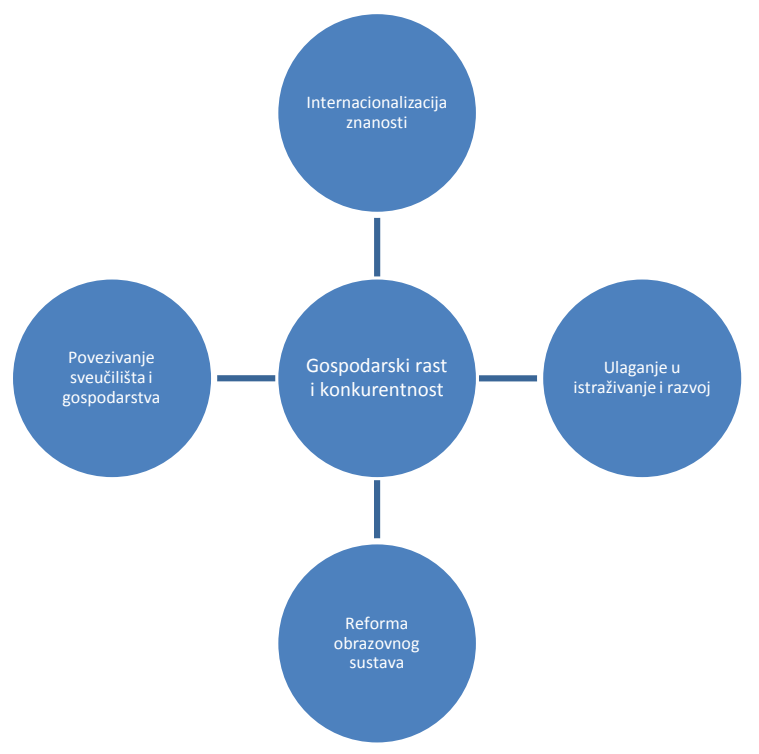

Izvor: izrada autora.

Unatoč definiranim strategijama te ambiciozno postavljenim ciljevima i planovima provedbe, Republika Hrvatska mora, u cilju ostvarivanja gospodarskoga rasta te implementacije ekonomije znanja, uz povećanje ukupnih ulaganja u istraživanje i razvoj, krenuti u temeljite aktivnosti unutarnjega preustroja vlastitih znanstveno-istraživačkih institucija te načela i principa njihova rada. Obrazovnome sustavu Republike Hrvatske potrebna je 
temeljita reforma te pomicanje s klasičnog, ex katedra pristupa, na interaktivni i inovativni sustav, a koji će pojedinca usmjeravati na promišljanja te povezivanje teorijskih i praktičnih znanja, a kako bi se u konačnici „stvorili““ gotovi stručnjaci, sposobni za integraciju na tržište rada. Također, obrazovnome sustavu potrebna je temeljita infrastrukturna obnova te cjelokupna informatizacija sustava. Nadalje, a što je istaknuto kao ključni cilj i u analiziranim strategijama, kao nužnost se nameće implementacija i komercijalizacija rezultata znanstvenih istraživanja na tržište, uz sve veći angažman poslovnoga sektora. Pritom je najveću pozornost potrebno posvetiti malim i srednjim poduzećima, koja predstavljaju generator ekonomske aktivnosti, ali koja su zbog različitih ograničenja „sputana“ u svojim znanstveno-istraživačkim i inovacijskim pothvatima. Kao što je i Audretsch (2007.) istaknuo, sveučilišta te implementacija njihovih produkata na tržište, u suradnji s malim i srednjim poduzećima, predstavlja temelj ostvarivanja budućega dugoročnog gospodarskog rasta. $\mathrm{Na}$ takav način će se potaknuti stvaranje novih, na znanju i inovacijama utemeljenih proizvoda te njihovim izvozom pokušati zauzeti veći udio na globalnome tržištu. Također, hrvatska sveučilišta, još uvijek relativno ,zatvorena“, moraju se okrenuti internacionalizaciji i suradnji s međunarodno priznatim inozemnim institucijama. Internacionalizacija bi se trebala odvijati u smjeru poticanja mobilnosti nastavnika, znanstvenika, studenata i ostaloga istraživačkog osoblja, u svrhu stvaranja novih znanja, izmjene dobrih praksi te unaprjeđenje međunarodne prepoznatljivosti. Nadalje, hrvatskim znanstvenicima trebala bi se osigurati sredstva za publikaciju rezultata njihova istraživanja u relevantnim međunarodnim časopisima, u svrhu ostvarenja međunarodne vidljivosti. Općenito, ostvarenje ekonomije znanja je opsežan i složen proces, koji zahtijeva međudjelovanje i zajedničku implementaciju svih prethodno navedenih elemenata uz uvažavanje nacionalnih razvojnih ciljeva. Pritom, kao ključno pitanje i izazov nameće se ostvarenje međunarodne izvrsnosti.

Prethodno analizirane strategije su prije svega usmjerene povećanju ukupnih ulaganja u istraživanje i razvoj te općenito poboljšanju znanstveno-istraživačke pozicije Republike Hrvatske na europskoj i međunarodnoj razini. Projekcije provedene korištenjem metode eksponencijalnog izglađivanja ukazuju na nastavak povećanja ulaganja u istraživanje i razvoj u Republici Hrvatskoj (grafikon 14.) u razdoblju 2017. - 2020. godine.

Grafikon 14. Projekcije ulaganja u istraživanje i razvoj (\% BDP-a) u Republici Hrvatskoj i EU u razdoblju 2016. - 2020. godine

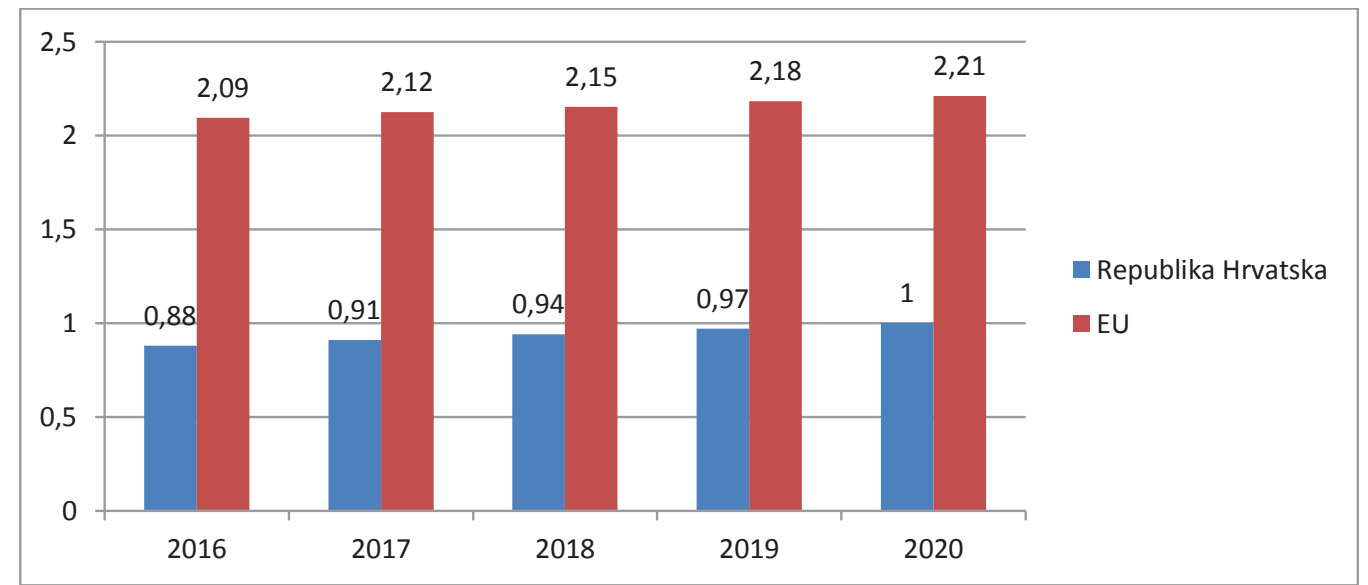

Izvor: izračun autora. 
Naime, u promatranome razdoblju Republika Hrvatska bi trebala dosegnuti razinu ulaganja od $1 \%$ BDP-a do 2020. godine. Navedena situacija će predstavljati određeni napredak s obzirom na sadašnje stanje. Ipak, i s takvim relativnim povećanjem, Republika Hrvatska će se i dalje nalaziti ispod razina propisanih europskim strategijama (3\% BDP-a) te Inovacijskom strategijom Republike Hrvatske (1,4 \% BDP-a). Također, očekivanim vrijednostima u 2018. godini (0,94 \% BDP-a), Republika Hrvatska će se približiti ostvarenju ciljeva propisanih Strateškim planom za razdoblje 2016. - 2018. godine (0,98 \% BDP-a). $\mathrm{S}$ druge strane, ulaganja u istraživanje i razvoj na razini EU bi, sukladno projekcijama, trebala dosegnuti razinu od 2,21\% BDP-a, čime neće biti ostvareni ciljevi propisani strategijom EUROPA 2020. Isto tako, u smislu ostvarenja ostalih ciljeva, Strategija ne bilježi značajnije ostvarenje rezultata te je krajnje upitno koji će ciljevi biti stvarno dosegnuti do predviđenoga roka, tj. 2020. godine. Ipak, uvažavajući nacionalne specifičnosti, trenutačnu složenu i nesređenu političku situaciju, još uvijek veliki nedostatak svijesti o značaju suvremenih izvora rasta, nesklonost nositelja gospodarske djelatnosti suvremenim tehnološkim rješenjima te stalno inovacijsko i znanstveno-tehnološko zaostajanje, rezultate projekcija je, posebno u slučaju Republike Hrvatske, potrebno uzeti s određenom mjerom opreza. Kao što je prethodno navedeno, Republika Hrvatska mora nastaviti stvarati povoljne uvjete za oporavak gospodarstva temeljen na znanju i njegovim produktima, uz pokretanje efikasnih i učinkovitih strukturnih promjena.

\section{ZAKLJUČAK}

Provedenim istraživanjem utvrđena je nepovoljna gospodarska situacija u Republici Hrvatskoj, nastala prije svega kao posljedica povijesnog nasljeđa te kao rezultat globalne ekonomske krize, a kojom je Republika Hrvatska bila pogođena najviše od svih zemalja članica EU. Općenito, kao ključni gospodarski problemi su identificirani niska razina BDP-a per capita, visoka stopa nezaposlenosti, niska stopa zaposlenosti te još uvijek visoki udio dodane vrijednosti BDP-a te zaposlenosti, vezan uz aktivnosti primarnoga i sekundarnoga sektora. Znanstveni doprinos provedenoga istraživanja proizlazi iz sistemskoga pregleda dosadašnjih istraživanja, koja identificiraju ulaganja u istraživanje i razvoj kao čimbenik ostvarenja gospodarskoga rasta u suvremenim, globaliziranim uvjetima. Nadalje, temeljem pregleda literature, $\mathrm{u}$ radu je provedena analiza ovoga segmenta na razini Republike Hrvatske te izvršena usporedba s prosjekom EU. Navedenim je dokazana krajnje nepovoljna situacija Republike Hrvatske u ovome segmentu. Naime, država još uvijek ostvaruje niske razine ulaganja u istraživanje i razvoj uz nizak angažman poslovnoga sektora, a koja bi, sukladno europskim i nacionalnim strategijama, trebala predstavljati ključan izvor promjena. Nadalje, obrazovna struktura je još uvijek nepovoljna i što je najvažnije neusklađena s potrebama tržišta rada, a što za rezultat ima visoku razinu nezaposlenosti mladoga i obrazovanoga stanovništva. Općenito, Republika Hrvatska zaostaje i u ostalim područjima (broj novih doktora znanosti, broj istraživača, izvoz proizvoda visoke tehnologije), a čija bi implementacija i napredak trebali omogućiti boljitak i povećanje konkurentnosti nacionalnoga gospodarstva. Temeljem analiziranih strategija, u radu je predložen i autorski koncept razvojne strategije, koji uz nacionalne razvojne prioritete, identificira ulaganja u istraživanje i razvoj, reformu obrazovnoga sustava, povezivanje sveučilišta i gospodarstva te internacionalizaciju cjelokupnoga znanstvenog sustava, kao ključ gospodarskoga rasta i 
oporavka hrvatskoga gospodarstva. Nadalje, u radu je provedena projekcija kretanja ulaganja u istraživanje i razvoj u Republici Hrvatskoj do 2020. godine, a čiji rezultati upućuju na dosezanje razine od 1 \% BDP-a. Ipak, uvažavajući cjelokupnu „klimu“ i provedbu inovacijskih i znanstveno-tehnoloških politika na razini Republike Hrvatske, ovakve je rezultate potrebno uzeti s određenom razinom opreza. Ovako provedenim istraživanjem ostvareni su svrha i cilj istraživanja.

Općenito, premda proklamirana kao važan cilj, realizacija ekonomije i društva znanja u Republici Hrvatskoj još se uvijek nalazi u „povojima“, a čemu je uvelike pridonijela i nepovoljna gospodarska, a u zadnje vrijeme i nestabilna politička situacija. Pritom, ulaganja u istraživanje i razvoj te prateći produkti predstavljaju priliku, ali i izazov u smislu ostvarenja gospodarskoga rasta i smanjivanja razvojnih razlika u odnosu na ostale zemlje članice EU.

\section{LITERATURA:}

\section{Knjige:}

1. Armstrong, H., Taylor J. (2000). Regional economics and policy, Oxford: Blackwell Publishing.

2. Clark, C., (1957). The Conditions of Economic Progress. London: Macmillan.

3. Griliches, I. (1998). R\&D and productivity: The Econometric Evidence. Chicago: University of Chicago Press.

4. Grossman G. M., Helpman E. (1990). Innovation and Growth in the Global Economy. Cambridge: MIT Press.

5. Kaldor, N. (1966). Causes of the Slow Rate of Economic Growth of the United Kingdom“. Cambridge: Cambridge University Press.

6. Kandžija, V.; Cvečić, I. (2010). Ekonomika i politika Europske unije. Rijeka: Ekonomski fakultet Sveučilišta u Rijeci.

7. Mincer, J. (1974). Schooling, Experience and Earnings. New York: NBER Press.

\section{Članci u časopisima:}

1. Aghion, P., Howitt P. (1992). „A Model of Growth through Creative Destruction“, Econometrica, (60), 2, 323-351.

2. Aghion, P., Bloom, N., Blundell, R., Griffith, R., Howitt, P. (2005). „Competition and Innovation: An Inverted-U Relationship“, The Quarterly Journal of Economics, (120), 2.

3. Audretsch, D. B., Feldman, M. P. (1997). "R\&D spillovers and the geography of innovation and production", American Economic Review, (86), 4, 253-273.

4. Bečić, E., Dabić, M. (2008). „Analiza ulaganja poslovnog sektora Republike Hrvatske u istraživanje i razvoj“, Revija za sociologiju, (39), 1-2, 69-84.

5. Cheshire, P., Malecki E. (2005). „Growth, development and innovation: a look backward and forward“, Papers in Regional Science, (83), 1, 249-267. 
6. Easterlin, R. (1981). „Why isn’t the Whole World Developed?“, Journal of Economic History, (41), 1, 1-19.

7. Fagerberg J., Verspagen B., Caniëls M. (1997). „Technology, Growth and Unemployment across European Regions“", Taylor and Francis Journals, (31), 5, 457-466.

8. Guellec, D., van Pottelsberghe, B. (2003). „The impact of public R\&D expenditure on business R\&D“, Economics of innovation and new technology, (12), 3, 225-243.

9. Krstić, B., Džunić, M. (2014). „Analysis of the Western Balkan countrie's competitiveness determinants using the KEI methodology“, Ecoforum, (3), 2.

10. Lever, W. F. (1991), „Deindustrialisation and the Reality of the Post-industrial City“, Urban Studies, (28), 6, 983-999.

11. Lucas, R. E. (1988). „On the mechanics of economic development“, Journal of Monetary Economics, (22), 3-42.

12. Mankiw, G., Romer, D. and Weil, D. (1992). „A contribution to the empirics of economic growth“, Quarterly Journal of Economics, (107), 2, 407-437.

13. Romer, P. M. (1986). Increasing Returns and Long-Run Growth. The Journal of Political Economy, (94), 5, 1002-10037.

14. Romer, P. M. (1990)., Endogenous technological change, Journal of Political Economy, (98), 5, 71-102.

15. Pereira, J., and Aubyn M., St. (2009). „What Level of Education Matters Most For Growth? Evidence From Portugal”, Economics of Education Review, (28), 1, 67-73.

16. Sala-i-Martin, X. (1996). „The Classical Approach to Convergence Analysis“, Economic Journal, (106), 473, 1019-1036.

17. Solaki, M. (2013). „Relationship Between Education and GDP Growth: A Bi-variate Causality Analysis for Greece“, International Journal of Economic Practices and Theories, (3), 2, 133-139.

18. Solow, R. M. (1956). „A contribution to the theory of economic growth“, Quarterly Journal of Economics, (70), 1, 65-94.

19. Solow, R. M. (1957). „Technical Change and the Aggregate Production Function“, The Review of Economics and Statistics, (39), 3, 312-320.

20. Stevens, P., Weale, M. (2003). „Education and economic growth“, National Institute of Economic and Social Research, London, Great Britain, 1-25.

21. Šimurina, J. (2004). „State of the Level of Technology in Central and East Europe“, Zagreb International Review of Economics \& Business“, (7), 2, 95-106.

22. Šimurina, J. (2006). „Creation and Transfer of Technology in CEE Countries“, Zagreb International Review of Economics \& Business, (9), 1, 77-98.

23. Švarc, J. (2014). ,A Triple Helih systems approach to strengthening innovation potential of the Western Balkan countries", International journal of transitions and Innovation system, (3), 2.

24. Winters, P. R. (1960). „Forecasting Sales by Exponentially Weighted Moving Averages“, Management Science, 6(3), 324-342. 


\section{Članci u Zborniku:}

1. Bouaissa, M. (2009). „Human Capital Theory, Returns to Education and On the Job Learning: Evidence From the Canadian Data“. u: CEA 43rd Annual Conference, University of Toronto, Ontario.

2. Dabić, M. (2007). „Innovation and transfer technology“, u: Komercijalizacija i društvena primjena znanosti - indijska i hrvatska iskustva, Hrvatska iskustva, Zagreb: MZOŠ i HIT.

3. Cairncross, A. (1982). „What is deindustrialisation?“, u: Deindustrialisation (Blackaby, F. (ed.), London: National Institute of Economic and Social Research, Economic Policy Papers, Heinemann Educational Books.

4. Damian, D., Lanubile, F., Oppenheimer, H. L. (2003). ,Addressing the Challenges of Software Industry Globalization“, The Workshop on Global Software Development, u: Proceedings of 25th International Conference on Software Engineering. Los Alamitos: IEEE Computer Society, 793-794.

5. Prodanović, S., Petković, D., Bašić, H. (2013). „Istraživanje inovacionog potencijala BiH s aspekta upravljanja i odlučivanja o RDI aktivnostima“, 8. Znanstveno-stručni skup sa međunarodnim sudjelovanjem ”KVALITET 2013”, Neum, Bosna i Hercegovina.

\section{Ostalo:}

1. Ahmed, S. (2009). „Human Capital and Regional Growth: A Spatial Econometric Analysis of Pakistan“, Florence, Italy, doktorska disertacija.

2. Audretsch, D. B., Alridge, T., Oettl, A. (2006). "The knowledge filter and economic growth: The role of Scientist Enterpreneurship", Jena, Germany, Max Planck Institute of Economics, Discussion Papers on Enterpreneurship, Growth and Public Policy.

3. Barro, R. J. (1998). "Notes on growth accounting", Cambridge, United Kingdom, National Bureau of Economic Research, Working paper, No. 6654.

4. Bjorksten, N. J. (2000). "Real convergence in the enlarged Euro area: a coming challenge for monetary policy", Helsinki, Finland, Bank of Finland Economics Department. Working paper no. 1/2000.

5. Puljiz, J. (2009). „Čimbenici regionalnog razvoja i regionalnih nejednakosti u Republici Hrvatskoj“, Sveučilište u Splitu, Ekonomski fakultet Split, doktorska disertacija.

6. Lawson, C. (1997). "Territorial Clustering and High Technology Innovation: From Industrial Districts to Innovative Milieux", ESRC Centre for Business 234 Research, Working paper no. 54.

\section{Internet:}

1. AMECO, 2016, dostupno na: http://appsso.eurostat.ec.europa.eu/nui/submitViewTableAction.do, 2016.

2. Eurostat (1): http://ec.europa.eu/eurostat/tgm/refreshTableAction.do?tab=table\&plugin $=1 \&$ pcode $=$ tsdec100\&language $=$ en, 2017. 
3. Eurostat (2): http://ec.europa.eu/eurostat/web/lfs/data/database, 2017.

4. Eurostat (3): http://ec.europa.eu/eurostat/web/science-technologyinnovation/data/database, 2017.

5. Eurostat (4): http://ec.europa.eu/eurostat/web/education-and-training/data/database, 2017.

6. Eurostat (5): http://ec.europa.eu/eurostat/statisticsexplained/index.php/Lifelong_learning_statistics, 2017.

7. Ministarstvo gospodarstva, poduzetništva i obrta (1): http://www.mingo.hr/page/prijedlog-strategije-poticanja-investicija-u-republici-hrvatskoj-za-razdoblje-2014-202030-svibnja-14-lipnja-2014, 2017.

8. Ministarstvo gospodarstva, poduzetništva i obrta (2): http://www.mingo.hr/page/donesena-strategija-poticanja-inovacija-republike-hrvatske-2014-2020, 2017.

9. Ministarstvo gospodarstva, poduzetništva i obrta (3): http://www.mingo.hr/page/vlada-usvojila-strategiju-pametne-specijalizacije-rh-za-razdoblje-2016-2020, 2017.

10. Ministarstvo znanosti obrazovanja i sporta: http://public.mzos.hr/Default.aspx?art= 10679, 2017.

11. OBZOR 2020: http://www.obzor2020.hr/, 2017.

12. Svjetska banka (1) : http://data.worldbank.org/indicator/NV.AGR.TOTL.ZS, 2016.

13. Svjetska banka (2): http://data.worldbank.org/indicator/NV.IND.TOTL.ZS, 2016.

14. Svjetska banka (3): http://data.worldbank.org/indicator/NV.SRV.TETC.ZS, 2016.

15. Svjetska banka (4): http://data.worldbank.org/indicator/SL.AGR.EMPL.ZS, 2016.

16. Svjetska banka (5): http://data.worldbank.org/indicator/SL.IND.EMPL.ZS, 2016.

17. Svjetska banka (6): http://data.worldbank.org/indicator/SL.SRV.EMPL.ZS, 2016.

18. Svjetska banka (7): http://data.worldbank.org/indicator/TX.VAL.TECH.MF.ZS, 2016. 